US Army Corps of Engineers $s_{\circledast}$

Engineer Research and

Development Center

Flood and Coastal Systems Research and Development Program

\title{
Development and Application of the CASM-SL to Support Nutrient Management in Potential Sangamon River Levee Setbacks
}

Steven M. Bartell, Cindy T. Woodard, Charles H. Theiling,

May 2020 and Travis A. Dahl

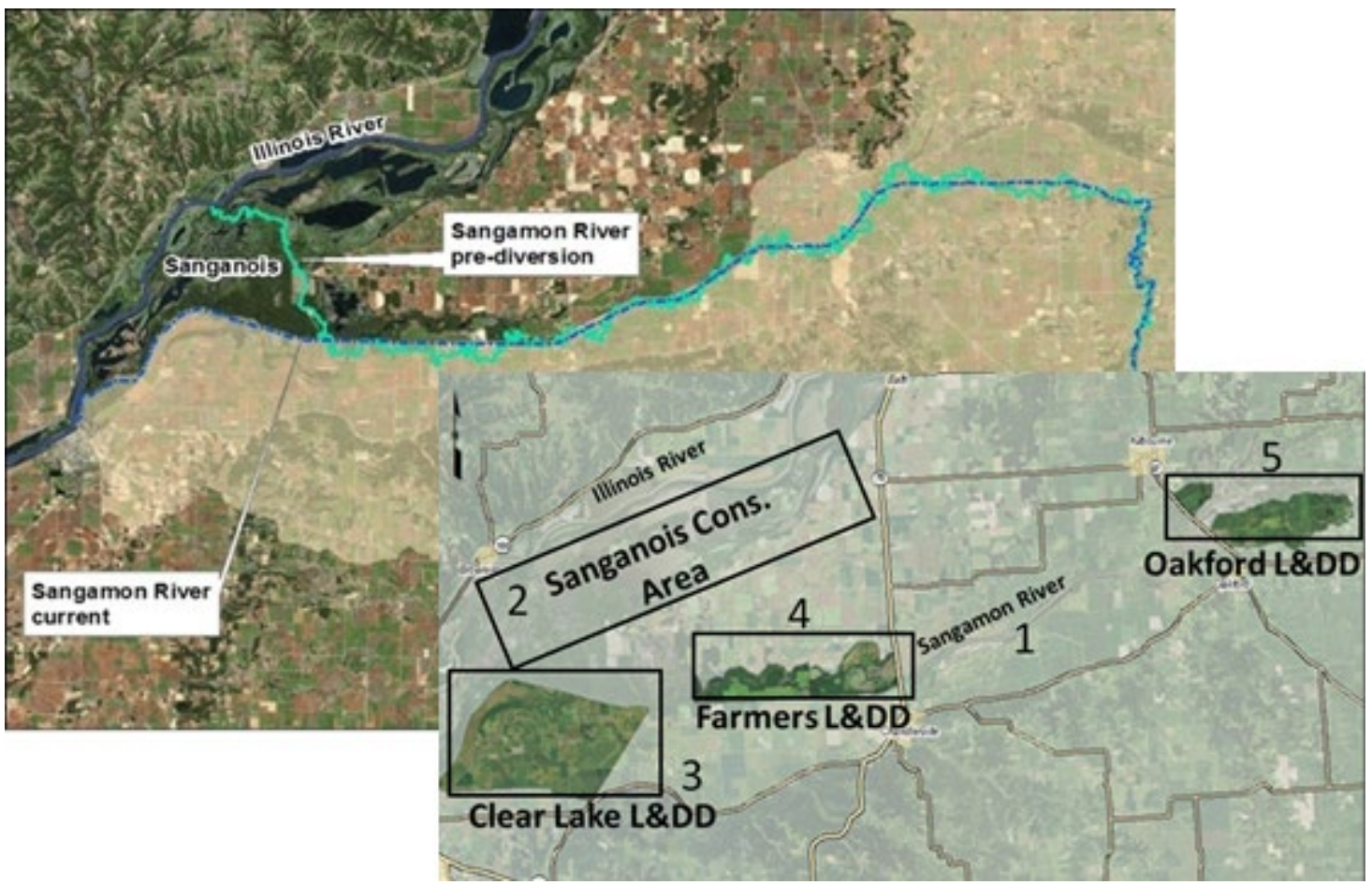


The US Army Engineer Research and Development Center (ERDC) solves the nation's toughest engineering and environmental challenges. ERDC develops innovative solutions in civil and military engineering, geospatial sciences, water resources, and environmental sciences for the Army, the Department of Defense, civilian agencies, and our nation's public good. Find out more at www.erdc.usace.army.mil.

To search for other technical reports published by ERDC, visit the ERDC online library at http://acwc.sdp.sirsi.net/client/default. 


\title{
Development and Application of the CASM-SL to Support Nutrient Management in Potential Sangamon River Levee Setbacks
}

\author{
Travis A. Dahl \\ Coastal and Hydraulics Laboratory \\ US Army Engineer Research and Development Center \\ 3909 Halls Ferry Rd \\ VIcksburg, MS 39180-6199 \\ Charles H. Theiling \\ Environmental Laboratory \\ US Army Engineer Research and Development Center \\ 3909 Halls Ferry Rd \\ VIcksburg, MS 39180-6199 \\ Steven M. Bartell and Cindy T. Woodard \\ Cardno, Inc. \\ 7610 Morganton Road \\ Greenback, TN 37742
}

Final report

Approved for public release; distribution is unlimited.

Prepared for US Army Corps of Engineers

Washington, DC 20314-1000

Under Project 454633, "Evaluation of Levee Setbacks and River Restoration Projects for Flood Risk Reduction" 


\section{Abstract}

Levee setbacks are defined by the intentional relocation of levees away from the river bank. This placement is often done to reduce flood risk, but it can also have environmental benefits. The Comprehensive Aquatic System Model (CASM) was used to look at the potential fate of nutrients and several environmental benefits for five potential management scenarios along the lower Sangamon River in Illinois. The model results showed that two scenarios were much more environmentally favorable relative to the outcomes considered here. One of the scenarios, where the existing gates were operated to allow the river access to the area behind the levee during extreme floods, was better at nitrogen and phosphorous accumulation. Removing the gates and creating a levee setback at this same site produced more aquatic plants, invertebrates, and fish but was not as effective at nutrient accumulation. This application of CASM demonstrates the potential of the model to provide objective rankings for the environmental benefits of levee setbacks.

DISCLAIMER: The contents of this report are not to be used for advertising, publication, or promotional purposes. Citation of trade names does not constitute an official endorsement or approval of the use of such commercial products. All product names and trademarks cited are the property of their respective owners. The findings of this report are not to be construed as an official Department of the Army position unless so designated by other authorized documents. 


\section{Contents}

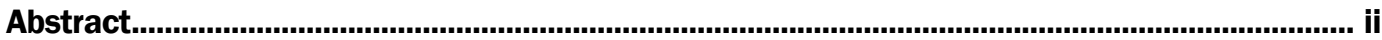

Figures and Tables......................................................................................................................................

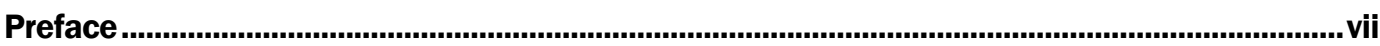

1 Introduction............................................................................................................................... 1

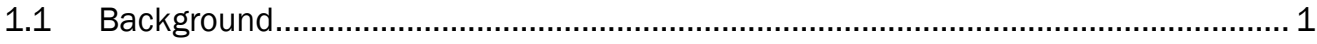

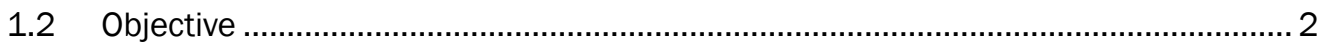

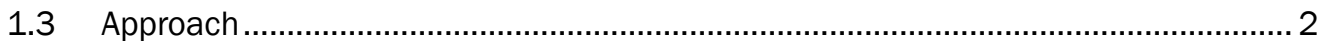

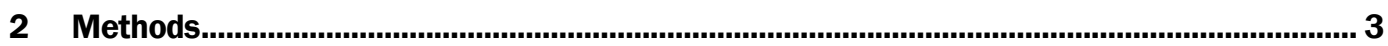

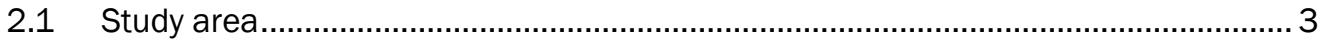

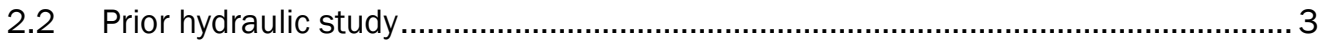

2.3 Model description................................................................................................. 4

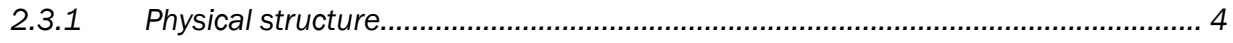

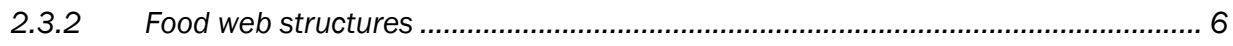

2.3.3 Bioenergetics and habitat quality parameters.................................................. 8

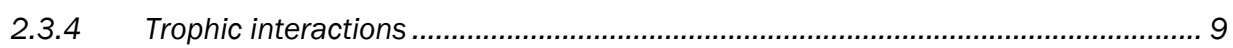

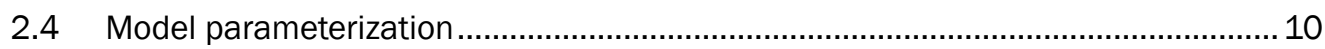

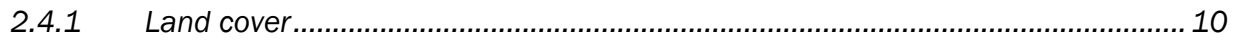

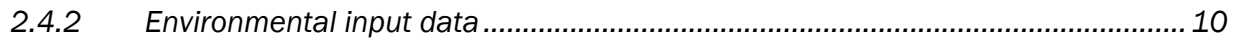

2.4.3 Surface light intensity .................................................................................. 11

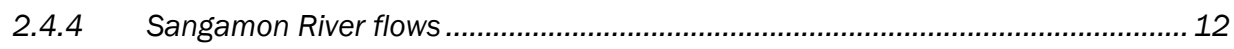

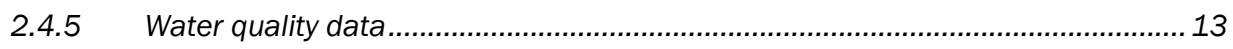

2.4.6 Modeled nutrient dynamics.......................................................................... 15

2.5 Model application ...................................................................................... 17

2.5.1 Integration of HEC-RAS results with the CASM-SL .......................................... 17

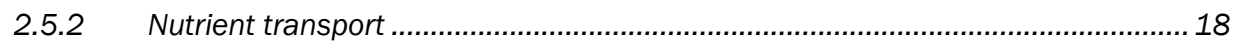

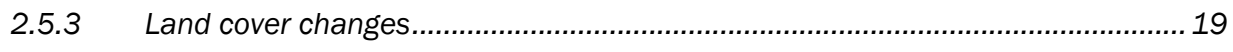

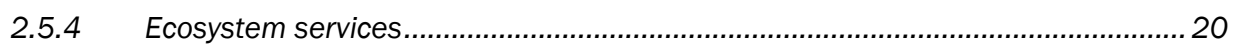

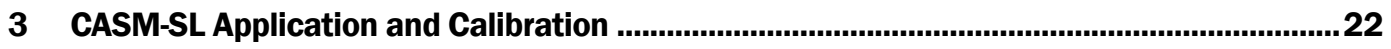

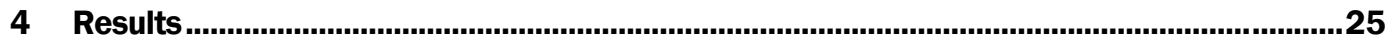

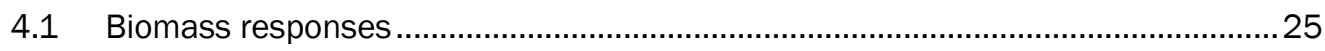

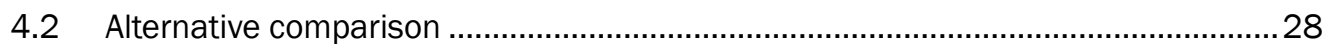

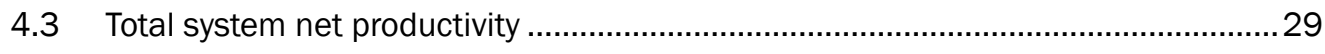

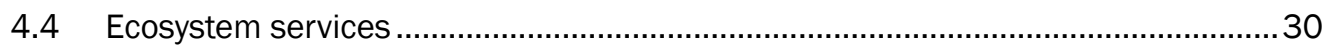

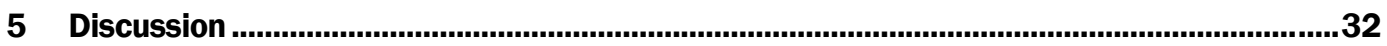

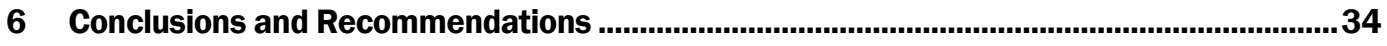

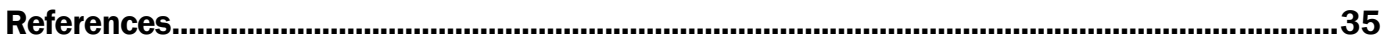




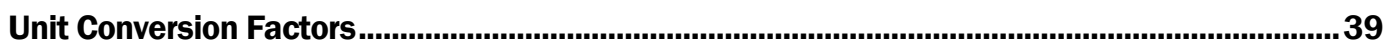

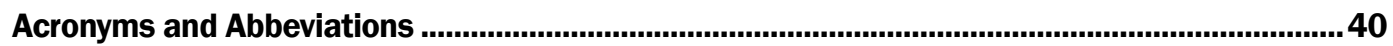

Report Documentation Page 


\section{Figures and Tables}

\section{Figures}

Figure 1. Location map showing Beardstown, IL, at the confluence of the Sangamon and Illinois Rlvers.

Figure 2. Box-model physical representation of the spatial segments (nodes) and spatial extent of the CASM-SL. (The box for Segment 1, the Sangamon River, is not shown.)

Figure 3. Daily measured values of 2010 incident solar radiation (watts $/ \mathrm{m}^{2}$ ) for Springfield, IL, station in the National Solar Radiation Data Base.

Figure 4. Daily average Sangamon River flows $\left(\mathrm{m}^{3} / \mathrm{s}\right)$ for the CASM-SL based on USGS NWIS data from a sampling station near Oakford, IL.

Figure 5. Measured values (black dots) and regression results (solid line) for daily water temperatures based on 2010 data reported for the La Grange Pool. Days outside of the range of the data (winter) were assigned a value of $1^{\circ} \mathrm{C}$.

Figure 6. Measured values for nitrate (a lower limit for modeled DIN) reported for 2010 in the La Grange Pool.

Figure 7. Measured values for soluble reactive $\mathrm{P}$ (a proxy for modeled DIP) reported for 2010 in the La Grange Pool.

Figure 8. Measured values for total suspended solids (TSS) reported for 2010 in the La Grange Pool. Error! Bookmark not defined.

Figure 9. Comparison of modeled and measured rank order of relative abundance for 14 fish populations modeled by the CASM-SL (based on data provided in Barko et al. [2004]).

Figure 10. Baseline biomass for modeled submerged aquatic vegetation in the Sangamon River segment for the baseline condition.

Figure 11. Baseline daily net productivity for modeled macroinvertebrates populations in the Sangamon River segment.

Figure 12. Baseline daily net productivity of selected modeled fish populations in the Sangamon River segment.

Figure 13. Daily net productivity of modeled aquatic vegetation in the Oakford L\&DD for Alternative 3B.

\section{Tables}

Table 1. Outcomes for levee setback alternatives from Theiling et al. (2018) $\left(y d^{3}=\right.$ cubic yards).

Table 2. Estimated DIN and DIP daily concentrations for each modeled alternative daily loadings.

Table 3. Percentage changes in land cover computed from Theiling et al. (2018).

Table 4. Annual net productivity $\left(\mathrm{g} \mathrm{C} / \mathrm{m}^{2} / \mathrm{yr}\right.$ ) for modeled SAV in segment 5 (Oakford L\&DD). Baseline (1) refers to segment 1 (Sangamon River) baseline productivity.

Table 5. Annual net productivity $\left(\mathrm{g} \mathrm{C} / \mathrm{m}^{2} / \mathrm{y}\right)$ for modeled emergent aquatic plants in segment 3 (Clear Lake L\&DD) and segment 5 (Oakford L\&DD) for 3A and 3B.

Table 6. Relative (\%) changes in total system productivity for selected populations compared to baseline simulation. 
Table 7. Relative (\%) change in annual productivity of selected edible invertebrates and

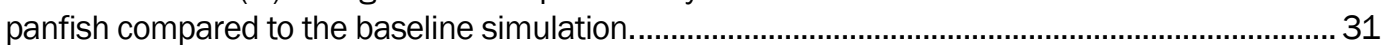

Table 8. Relative (\%) ecosystem function performance compared to baseline simulation.............. 31 


\section{Preface}

This study was conducted for the US Army Corps of Engineers, Flood and Coastal Systems Research and Development Program, under Project 454633, "Evaluation of Levee Setbacks and River Restoration Projects for Flood Risk Reduction." This work was initiated based on a request by the Office of Management and Budget to look at non-structural flood risk reduction. The program manager was Dr. Cary A. Talbot.

The work was performed by Cardno, Inc.; the Ecological Resources Branch of the Ecosystem Evaluation and Engineering Division, US Army Engineer Research and Development Center, Environmental Laboratory (ERDCEL); and the River Engineering Branch of the Flood and Storm Protection Division, ERDC, Coastal and Hydraulics Laboratory (CHL). At the time of publication of this report, Dr. Eric R. Britzke was Acting Chief, Ecological Resources Branch; Dr. Mark Farr was Chief, Ecosystem Evaluation and Engineering Division; and the Acting Director of ERDC-EL was Dr. Jack E. Davis. Mr. David P. May was Acting Chief, River Engineering Branch; Dr. Cary A. Talbot was Chief, Flood and Storm Protection Division; and Dr. Julie D. Rosati was the Technical Director for Flood and Coastal Systems. The Deputy Director of ERDC-CHL was Mr. Jeffrey R. Eckstein, and the Director was Dr. Ty V. Wamsley.

The Commander of ERDC was COL Teresa A. Schlosser, and the Director was Dr. David W. Pittman. 


\section{Introduction}

\subsection{Background}

Levee districts have disconnected more than $50 \%$ of the Illinois River floodplain from the main channel (Theiling 1995). Levee setbacks provide managers with alternatives to adapt to changing conditions, such as higher flows from upstream drainage and climate change (Dahl et al. 2017; Smith et al. 2017). Of interest in this study, levee setbacks on the lower Sangamon River (Illinois) have been proposed as alternatives to manage flood risks, reduce navigation channel maintenance dredging, and increase ecosystem management opportunities (Theiling et al. 2018).

Hydraulic models, such as the Hydrologic Engineering Center-River Analysis System (HEC-RAS) or Adaptive Hydraulics (AdH) can provide useful information about how levee setbacks may alter the flow of water and sediment in a river (Theiling et al. 2018; Jones et al. 2018). These models, however, do not provide information about how the ecosystem will change due to a levee setback and the associated change in nutrient dynamics. The results of the physical modeling may be integrated with an aquatic ecosystem model to characterize the corresponding food web and ecosystem risks and benefits.

The Comprehensive Aquatic System Model, CASM, (Bartell et al. 2017, 2013, 2010ab, 2000, 1999; Bartell 2003; DeAngelis et al. 1989) provides one such model for examining food web dynamics and nutrient management outcomes. CASM can be used to characterize nutrient transport during floods, including carbon $(\mathrm{C})$, nitrogen $(\mathrm{N})$, and phosphorous (P). CASM can also estimate the corresponding impacts on floodplain food webs and ecosystem function. Gergel et al. (2005) employed a statistical landscape model to examine the relative impacts of dams and levees on floodplain nitrate biogeochemistry. In contrast, the CASM presented herein provides a more process-oriented approach to modeling river and floodplain $\mathrm{C}$ and nutrient dynamics, particularly in relation to food web structures and ecosystem function. 


\subsection{Objective}

The goal of this study was to look at the potential impacts of levee setbacks and other levee modifications on nutrient management and food web outcomes. Levee setbacks move portions of a levee farther from the river channel and increase the amount of floodplain area accessible by the river during high flow events (Dahl et al. 2017). The approach presented here may be adapted to inform levee setback decisions throughout the country.

\subsection{Approach}

Theiling et al. (2018) created a 1-dimensional (1D) HEC-RAS hydraulic and sediment transport model of the lower Sangamon River and the confluence with the Illinois River. They estimated potential risks and benefits of five proposed levee setback designs on flood risk management, navigation channel maintenance, and ecosystem management. This report describes the use of the HEC-RAS model in conjunction with CASM to develop a food-web and nutrient model specific to the Sangamon levee districts (CASM-SL). Importantly, CASM-SL provided an alternative methodology for advancing from the qualitative scoring of ecosystem services (e.g., Theiling et al. [2018]) to more quantitative evaluations of relevant ecological outcomes.

This report describes the initial development of the CASM-SL and its application in characterizing the ecological risks and benefits of five proposed management alternatives for the lower Sangamon River (Sections 2 and 3). Selected representative results across different spatial scales, including system-wide summaries, are presented as preliminary indicators of the relative ecological and ecosystem outcomes of the management alternatives (Section 4). The report concludes with recommended next steps in refining the CASM-SL for future assessment of levee and drainage district (L\&DD) management actions (Sections 5 and 6). 


\section{Methods}

\subsection{Study area}

The study area is along the Sangamon River, upstream of the confluence with the Illinois River at Beardstown, IL (Figure 1). The focus of this modeling study was on the Sangamon River reach and associated levee and drainage districts identified as Clear Lake, Farmers, and Oakford in Theiling et al. (2018).

Figure 1. Location map showing Beardstown, IL, at the confluence of the Sangamon and Illinois RIvers.

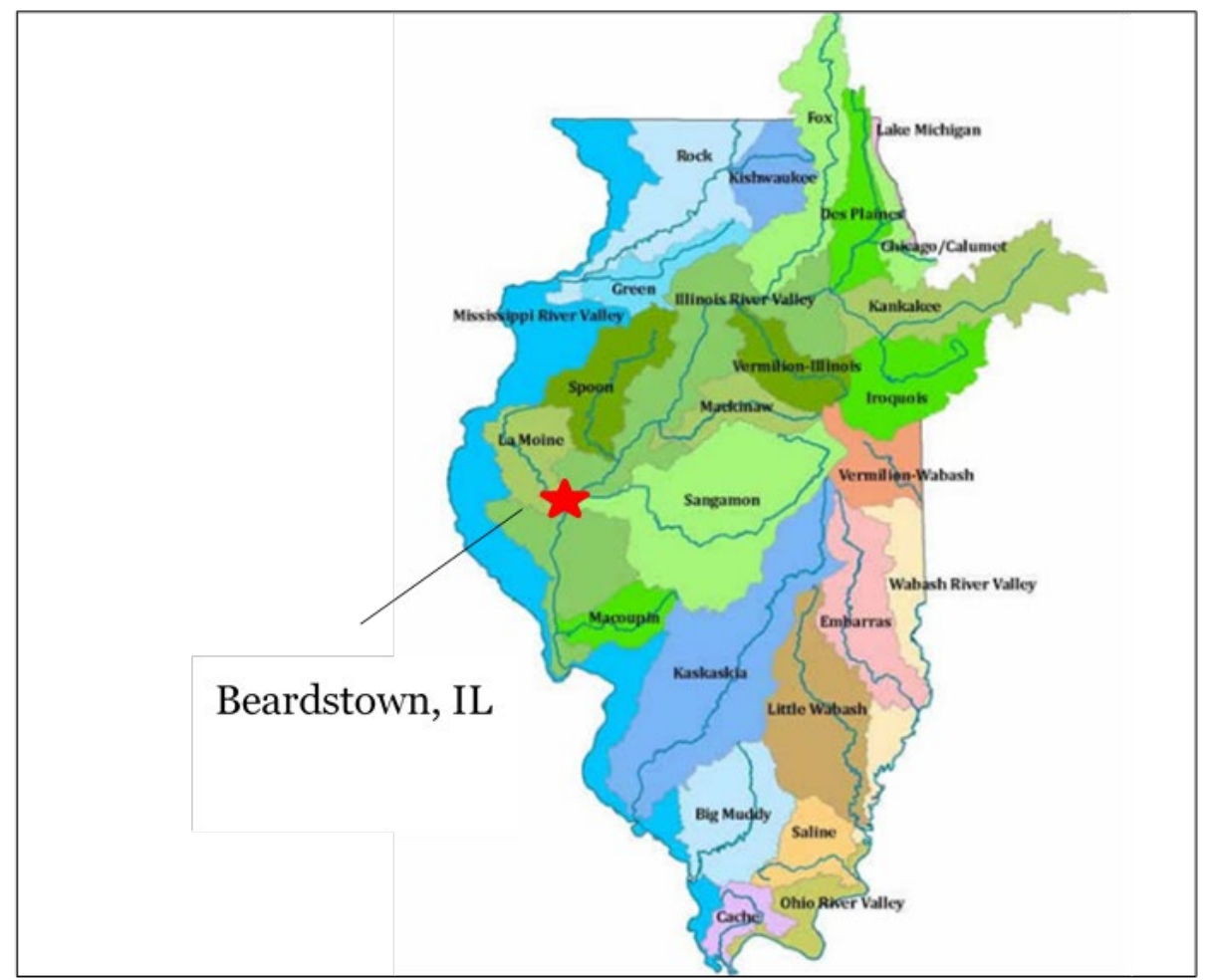

\subsection{Prior hydraulic study}

A HEC-RAS 1D hydraulic model was set up for 42 miles on the Illinois River and 47 miles on the Sangamon River to simulate sediment. The model was calibrated to the December 2015 - January 2016 flood event, which was similar in magnitude to many other historical floods in the basin (Theiling et al. 2018).

The calibrated HEC-RAS model was used as a baseline to compare simulations for five levee setback scenarios (see Theiling et al. 2018): 
- Alternative 1A - Clear Lake's gated inlet operated to prevent most flows, but opened during extreme floods

- Alternative $1 \mathrm{~B}$ - Clear Lake levee removal for stage reduction, sediment trapping, and increased floodplain connectivity, which would preclude most agriculture

- Alternative 2 - Farmer's natural levee removal for stage reduction, sediment trapping, habitat connectivity (e.g., restoring meanders), and increased flows to the Sanganois Conservation Area with minimal impacts on agriculture

- Alternative 3A-Oakford gated inlet operated for stage reduction, sediment trapping, and beneficial use of sediments

- Alternative $3 \mathrm{~B}$ - Oakford levee removal to address stage reduction, sediment trapping, and beneficial use of sediments.

HEC-RAS model results were summarized by Theiling et al. (2018) for the alternatives as follows:

- Peak river stage for the modeled flood

- Changes in bed profile compared to baseline

- Overbank deposition as volume of sediments diverted compared to baseline

- Flood risk management benefits

- Changes in land cover in setback areas (e.g., agricultural loss and habitat creation)

- Connectivity to wetlands, forest, and aquatic acres.

The initial CASM-SL assessment effort focused on the ecological outcomes of nutrient transport estimated for overbank sedimentation, conversion of agricultural lands to more natural habitat, and changes in connectivity to wetlands, forest, and aquatic areas.

\subsection{Model description}

The following sections describe the development and implementation of the CASM for the Sangamon Levee (the CASM-SL).

\subsubsection{Physical structure}

The initial CASM-SL used a simplified box model approach and represented the selected spatial units as landscapes/riverscapes characterized by different fractions of land cover (e.g., agriculture, 
bottomland forest, wetlands, and open water) variously interconnected by flows (e.g., overbank flooding). The CASM-SL spatial domain included river channel and overbank areas for the following spatial units (nodes) located in Macomb and Lincoln counties in Illinois (Figure 2):

- Node 1 - Sangamon River: The 47 miles $(76 \mathrm{~km}$ ) of the Sangamon River included in the HEC-RAS model represented widths ranging $62-181$ feet (ft), as described by Larson et al. (1994). The average surface area for this river reach was modeled as 741 acres. This riverscape was described initially as $95 \%$ open water with $4 \%$ wetlands and $1 \%$ bottomland forest.

- Node 2 - The Sangamon Conservation Area: This 10,360 acre area is a typical bottomland complex of sloughs, backwater lakes, ponds, and bottomland timber characterized mainly by willow, silver maple, and cottonwood. Land cover data indicate the conservation area is approximately $73 \%$ forest and $16 \%$ water (https://www.dnr.illinois.gov/hunting/factsheets/pages/sanganois.aspx).

- Node 3 - Clear Lake Levee and Drainage District: Based on the data provided in Theiling et al. (2018) and reproduced in Table 1, the Clear Lake L\&DD was modeled as 8,555 acres of largely agricultural lands (90\%) with $5 \%$ bottomland forest and $5 \%$ wetlands.

- Node 4 - Farmers Levee and Drainage District: Based on Table 1, the Farmers L\&DD was described as 3,468 acres with a land cover composition identical the Clear Lake L\&D.

- Node 5 - Oakford Levee and Drainage District: Theiling et al. (2018) describe the Oakford L\&DD as 3,149 acres, also similar in land cover to Clear Lake and Farmers L\&DDs (Table 1). 
Figure 2. Box-model physical representation of the spatial segments (nodes) and spatial extent of the CASM-SL. (The box for Segment 1, the Sangamon River, is not shown.)

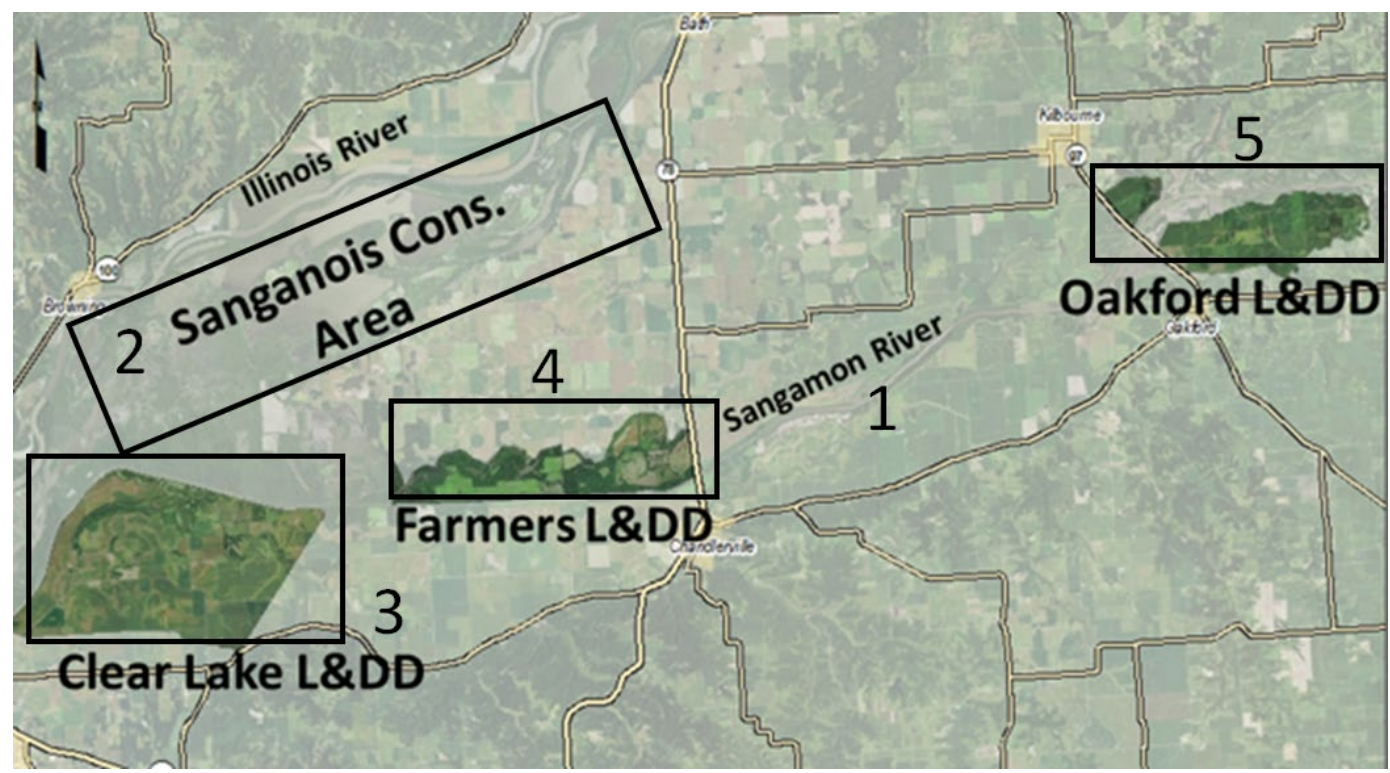

Table 1. Outcomes for levee setback alternatives from Theiling et al. (2018) ( $\mathrm{yd}^{3}=$ cubic yards).

\begin{tabular}{|l|c|c|c|c|c|}
\hline Benefit/Harm & Alt. 1A & Alt. 1B & Alt. 2 & Alt. 3A & Alt 3B \\
\hline Maximum stage reduction (ft) & 0.8 & 2.0 & 3.2 & 0.2 & 3.2 \\
\hline Bed-load retention (yd 3 ) & $-2,278$ & $-2,179$ & $-2,287$ & $-2,157$ & $-2,140$ \\
\hline Overbank retention (yd $\left.{ }^{3}\right)$ & $51,836,753$ & $54,318,062$ & $-1,390,838$ & $68,297,519$ & $-184,449,983$ \\
\hline Agriculture conversion (acre) & 0 & 6,939 & 1,333 & 0 & 2,849 \\
\hline Wetland connected (acre) & 0 & 39 & 110 & 0 & 2 \\
\hline Forest connected (acre) & 0 & 1,153 & 1,733 & 0 & 140 \\
\hline Aquatic connected (acre) & 0 & 54 & 175 & 0 & 0 \\
\hline Agriculture Index & -2 & -3 & -1 & -2 & -3 \\
\hline Habitat Index & 1 & 3 & 3 & 1 & 3 \\
\hline Ecosystem services Index & 2 & 3 & 1 & 2 & 3 \\
\hline Total acres in setback area & 8,555 & 8,555 & 3,468 & 3,149 & 3,149 \\
\hline
\end{tabular}

\subsubsection{Food web structures}

The technical literature that describes rivers and floodplains of the Upper Mississippi River (UMR) and Illinois Waterway was used to develop initial representative food web structures for riverine and floodplain ecosystems. The biomasses of populations identified in the following guilds of producers and consumers are represented as individual state variables in the CASM-SL. 
Floodplain forests - The model included the opportunity for newly formed land to be colonized by key floodplain forest species for example, cottonwood (Populus deltoides), willow (Salix spp.), silver maple (Acer saccharinum), and elm (Ulmus spp.) as described in the literature for southern Illinois (Yin et al. 1997; Hosner and Minckler 1963).

Emergent aquatic vegetation (EAV) - Sagittaria dominated the EAV in Big Lake, IA, a backwater lake proximate to Pool 9 (Eckblad et al. 1977). Scenarios that removed levees involved replacing crops with barnyard grass (Echinochloa crus-galli), chufa flatsedge (Cyperus esculentus), and smartweed (Polygonum pensylvanicum). The modeled EAV also included cattail (Typha latifolia) and the common reed (Phragmites australis).

Submerged aquatic vegetation (SAV) - The macrophyte communities along channel borders in the UMR are typically dominated by Vallisneria, Potamogeton, Ceratophyllum, and Nymphaea (e.g., Peck and Smart 1986). Model state variables were defined to represent these species in the CASM-SL food web.

Algae - Phytoplankton and attached algae were each represented by three separate populations of functionally defined diatoms (Bacillariophyceae), green algae (Chlorophyta), and blue-green algae (Cyanophyceae).

Zooplankton - Generalized populations of microzooplankton (protozoa), rotifers (Keratella spp.), cladocerans (Daphnia spp.), copepods (Diaptomus spp.), and ostracods (Ostracoda) defined the zooplankton assemblage in the CASM-SL.

Macroinvertebrates - The UMR and the lower Illinois River are large bottomland rivers in the Midwest. They are in similar ecoregions and have similar ecological communities. Macroinvertebrates in side channels of Pool 26 on the UMR were dominated by chironomids (Chironomus spp.), oligochaetes (Oligochaeta), mayflies (Hexagenia), and net-spinning caddisflies (Trichoptera) (Anderson and Day 1986). Similarly, Eckblad et al. (1977) reported dominance of mayflies (Hexagenia spp.) and sphaerid clams (Spharideae) in the benthos of Big Lake, a floodplain backwater lake on Pool 9 in northeastern Iowa. Correspondingly, the model includes state variables for each of these benthic invertebrates. An amphipod (Hyalella spp.) state variable was also defined as part of the macroinvertebrate community in the CASM-SL. 
Fish - Fish community structure in the Illinois River has changed substantially since the 1850 os, primarily as the result of human activities (Karr et al. 1985). At present, the numerically dominant fish identified from Long Term Resource Monitoring Program sampling of the main channel border of the unimpounded UMR and several navigation pools included shortnose gar (Lepisosteus platostomus), gizzard shad (Dorosoma cepedianum), red shiner (Cyprinella lutrensis), common carp (Cyprinus carpio), emerald shiner (Notropis atherinoides), river carpsucker (Carpiodes carpio), smallmouth buffalo (Ictiobus bubalus), channel catfish (Ictalurus punctatus), white bass (Morone chrysops), bluegill (Lepomus macrochirus), and freshwater drum (Aplodinotus grunniens) (e.g., Chick et al. 2006; Barko et al. 2004; Pegg and McClelland 2004; Madejczyk et al. 1998; Lubinski et al. 1986). A juvenile (aggregated early life stages) and adult state variable was implemented for each of these fish species in the CASM-SL.

\subsubsection{Bioenergetics and habitat quality parameters}

Mathematically, the CASM-SL is an interconnected system of linear differential equations with non-linear terms (e.g., temperature dependence of respiration). There is one equation for each modeled state variable, including the populations of producers, consumers, and decomposers, as well as one equation of each of the modeled water quality factors. Population dynamics in the CASM-SL are determined primarily by bioenergetics, and the detailed equations have been published previously (e.g., Bartell et al. 2013; Bartell et al. 2010a).

The general approach for developing bioenergetics and habitat quality parameter values was to use species-specific data and information where possible (e.g., Hartman 2017; Williamson and Garvey 2005; Putman et al. 1995; Randall et al. 1995) and to augment this information base by using data for taxonomically or ecologically similar species. In addition, allometric scaling was used for bioenergetics parameter estimation among species of similar taxonomy. FishBase (https://www.fishbase.org/) was used to identify relevant lifespans, average length, and length-weight functions used within the Wisconsin fish bioenergetics modeling formulations (e.g., Kitchell et al. 1977, 1974) to develop initial estimates of rates of consumption and respiration for modeled fish species.

The daily expression of bioenergetics-based growth for each modeled population (i.e., life stage) is modified by habitat quality parameters that 
are also dynamic in space and time. Photosynthesis rates by modeled algae are nonlinear functions of available light, water temperature, and concentrations of dissolved inorganic nitrogen (DIN), dissolved inorganic phosphorous (DIP), and dissolved silica (diatoms only). SAV and EAV in the model are assumed to meet their $\mathrm{N}$ and $\mathrm{P}$ requirements from sediment nutrient sources that are not included in the model. However, the bioenergetics of SAV and emergent aquatic plants are modified daily by values of light intensity, temperature, water current velocity, and water depth (e.g., Bartell 2017).

Rates of consumption and standard respiration are nonlinear functions of water temperature for the modeled consumer state variables. Consumer bioenergetics are also potentially modified by population-specific values of dissolved oxygen concentrations, water current velocity, and water depth (e.g., Bartell et al. 2010a).

The overall approach defines an integrated bioenergetics-habitat quality characterization of biomass dynamics within the CASM-SL. The CASM habitat quality parameters vary in space and time in relation to particular applications of the model, including the CASM-SL.

\subsubsection{Trophic interactions}

The technical literature, particularly fish diet information, was used to define grazing and predator-prey relations in the CASM-SL food web. This source of information was augmented by available data bases (e.g., FishBase) and other sources (e.g., recreational fishing websites).

Available studies were used to derive diet preferences for the modeled populations of aquatic consumers. For example, gizzard shad stomach contents from fish collected in shallow UMR waters were dominated by phytoplankton and zooplankton (Delong 2010). Sampson et al. (2009) noted that rotifers were the most commonly consumed prey item by gizzard shad in the Illinois (La Grange reach) and Mississippi Rivers (Pool 26). Age-o bluegill fed on zooplankton and chironomids whereas adults fed on a range of benthic invertebrates including chironomids (Delong 2010). Previous CASM applications (e.g., Bartell et al. 2010a) and professional judgment were also used to derive the initial diet matrices for the CASM-SL. 


\subsection{Model parameterization}

The following text describes site-specific parameterization of CASM for application in the Sangamon River for a focal year of 2010.

\subsubsection{Land cover}

The CASM-SL provides the capability to describe each modeled spatial segment (i.e., Nodes 1-5) by percentages of surface area defined by different land cover types. The initial CASM-SL includes the percentage of segment surface area occupied as agricultural lands, bottomland forest, wetlands, and open water. These baseline percentages for each L\&DD segment were revised according to the land cover changes suggested for each management alternative by the HEC-RAS modeling (i.e., Table 1).

Importantly, the overall ecological outcomes of the individual management alternatives simulated by the CASM-SL were determined by (1) modifications to habitat quality in the form of segment-specific nutrient transport (DIN, DIP) associated with the modeled flooding and the outcomes of individual management alternatives and (2) changes in the percentage of land cover (e.g., conversion of agricultural lands; connections to aquatic areas, wetlands, and forests) identified for each alternative. Changes in habitat quality influenced the daily (and annual) net productivity (grams of $\mathrm{C}$ per square meter per day [ $\mathrm{g} \mathrm{C} / \mathrm{m}^{2} /$ day]) of each modeled population. The spatial precision of the CASM-SL is $1 \mathrm{~m}^{2}$, although not all model inputs were derived from data at this level of resolution. Multiplying net productivity of each population by the area of its associated habitat provided an estimate of total population production (e.g., mass $\mathrm{C} /$ segment) for each management alternative.

\subsubsection{Environmental input data}

The CASM-SL simulates ecological production dynamics of the modeled populations as nonlinear functions of environmental input factors that vary in time and space, including surface light intensity, water current velocity, water depth, air and water temperature, and concentrations of dissolved inorganic N (DIN), dissolved inorganic P (DIP), dissolved silica, dissolved organic carbon (DOC), particulate organic carbon (POC), and suspended inorganic solids. 


\subsubsection{Surface light intensity}

Light intensity determines realized rates of photosynthesis for modeled populations of aquatic algae (i.e., phytoplankton and periphyton) and SAV in the CASM-SL. The model assumes that populations of both terrestrial and emergent aquatic plants are not light limited. Approximately $50 \%$ of the surface light intensity (watts $/ \mathrm{m}^{2}$ ) is photosynthetically active radiation (PAR) (McCree 1972).

Surface light intensity data were obtained for a station located in Springfield, IL, through the National Solar Radiation Data Base (http://rredc.nrel.gov/solar/old_data/nsrdb/). The year 2010 was selected as a representative of the region, and this year is the most recent year with available data for the Springfield station. Modeled and measured hourly values (watts $/ \mathrm{m}^{2}$ ) were obtained for 2010 and converted to daily values (Figure 3). The daily measured values were converted from watts $/ \mathrm{m}^{2}$ to PAR daily values with the units of einsteins $/ \mathrm{m}^{2} / \mathrm{d}$ to be used by the CASM$\mathrm{SL}$. The conversion integrates over the 400-700 nanometer wavelengths important for photosynthesis.

The CASM-SL attenuates incident surface light intensity in relation to concentrations of phytoplankton biomass, DOC, suspended POC, and suspended inorganic sediments. Intensities of PAR (einsteins $/ \mathrm{m}^{2} / \mathrm{d}$ ) are computed at $0.1 \mathrm{~m}$ depth increments and integrated over the water column to compute phytoplankton and SAV photosynthesis for each modeled segment. The CASM-SL uses a single depth layer for all five segments; however, water column depth for each segment varies daily in relation to flows and segment geometry. 
Figure 3. Daily measured values of 2010 incident solar radiation (watts $/ \mathrm{m}^{2}$ ) for Springfield, IL, station in the National Solar Radiation Data Base.

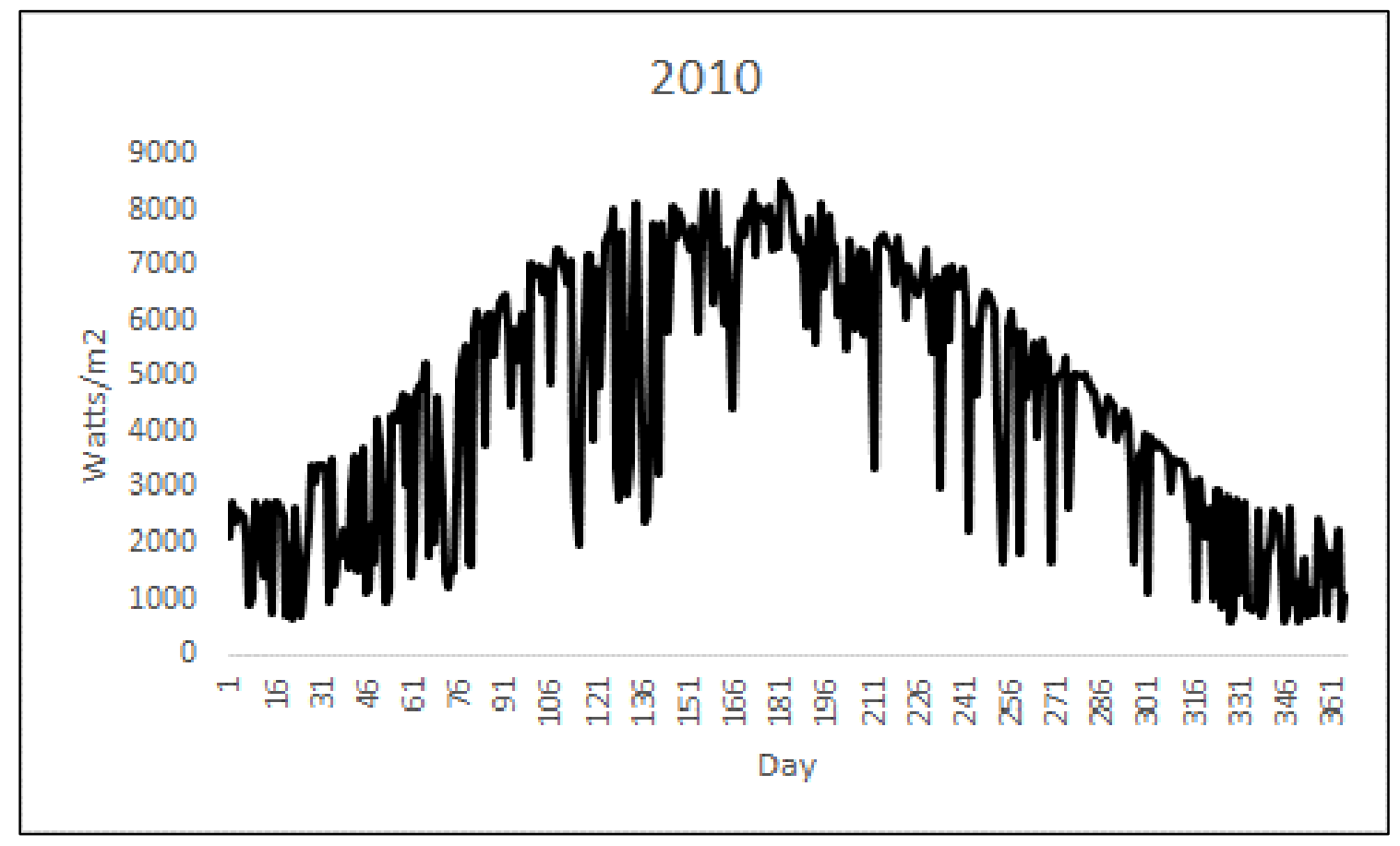

\subsubsection{Sangamon River flows}

Sangamon River flows and gauge heights were obtained for 2010 from the US Geological Survey (USGS) National Water Information System (NWIS) for the Site 05583000 near Oakford, IL

(https://waterdata.usgs.gov/nwis/uv?site_no=05583000). The 2010 discharge record ( $\mathrm{m} 3 /$ second [s]) near Oakford were assumed to represent the entire modeled reach of the Sangamon River included in the CASM-SL (Figure 4). The daily average discharge data were used to estimate corresponding values of river width, depth, and velocity using rating curves developed for the Sangamon River (Larson et al. 1994). 
Figure 4. Daily average Sangamon River flows $\left(\mathrm{m}^{3} / \mathrm{s}\right)$ for the CASM-SL based on USGS NWIS data from a sampling station near Oakford, IL.

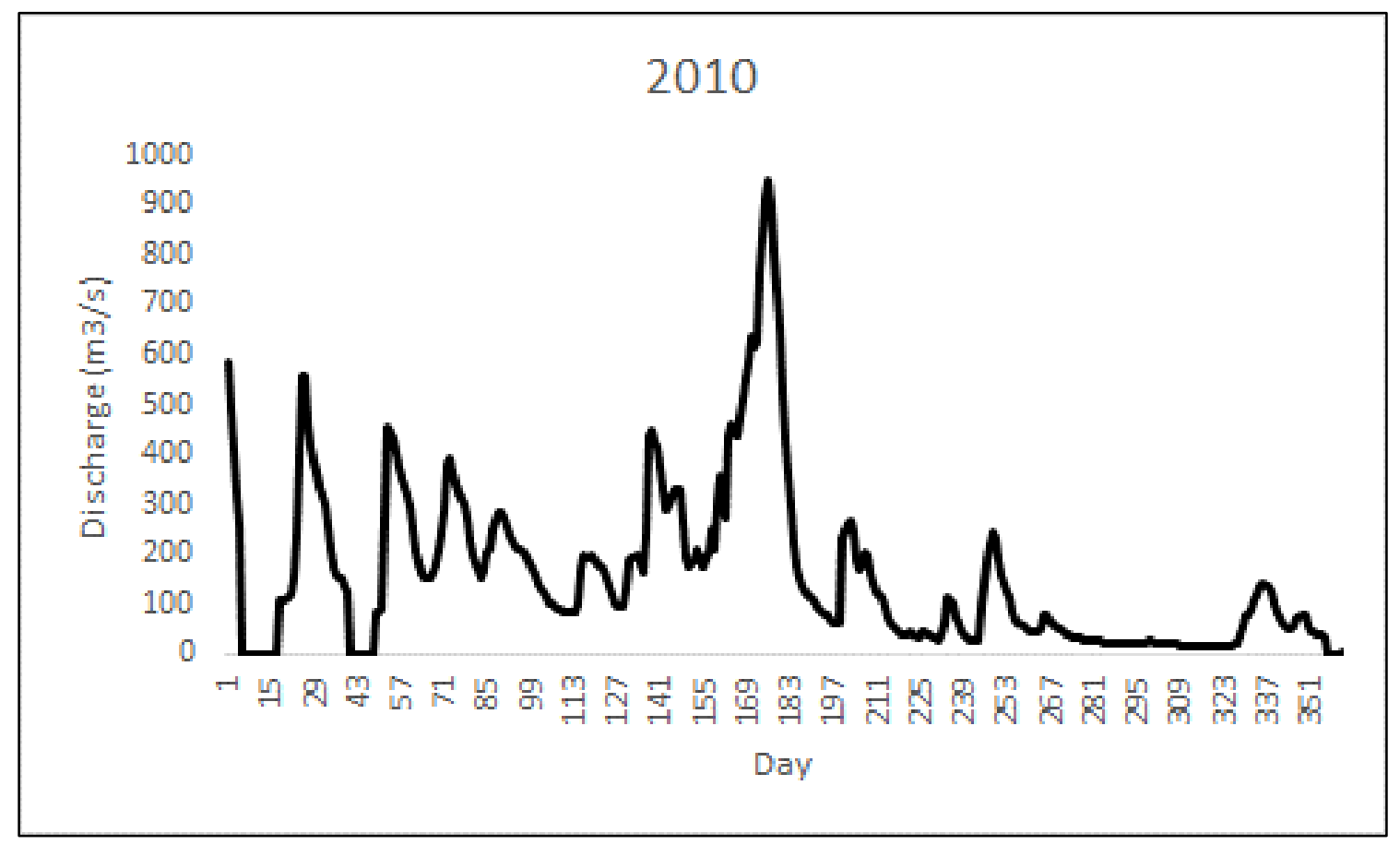

\subsubsection{Water quality data}

Water quality data for 2010 were obtained from the LaGrange Pool water quality location code SG16.2C (UTM: 743373, 4438599) from the Upper Midwest Environmental Sciences Center (https://www.umesc.usgs.gov/data_library/water_quality/poollg/locations/sg16.2c.shtml). The water quality parameters required by the CASM-SL that were obtained from this source include water temperature (Figure 5), nitrate (Figure 6; a lower limit for DIN), soluble reactive phosphorous (Figure 7; a proxy for DIP), and total suspended solids (Figure 8).

Polynomial regressions of these 2010 water quality data versus day of year were developed and used to construct daily values of these input data required by the CASM-SL (e.g., Figure 6). The polynomial regressions were used to compute the 365 daily values for water temperature, DIN, DIP, and total inorganic solids for each modeled segment.

The total suspended solids (TSS) data were subsequently partitioned to develop daily input values for POC and total inorganic solids based on fractions of TSS assumed to be POC (Bartell et al. 2010a). 
Figure 5. Measured values (black dots) and regression results (solid line) for daily water temperatures based on $\mathbf{2 0 1 0}$ data reported for the La Grange Pool. Days outside of the range of the data (winter) were assigned a value of $1^{\circ} \mathrm{C}$.

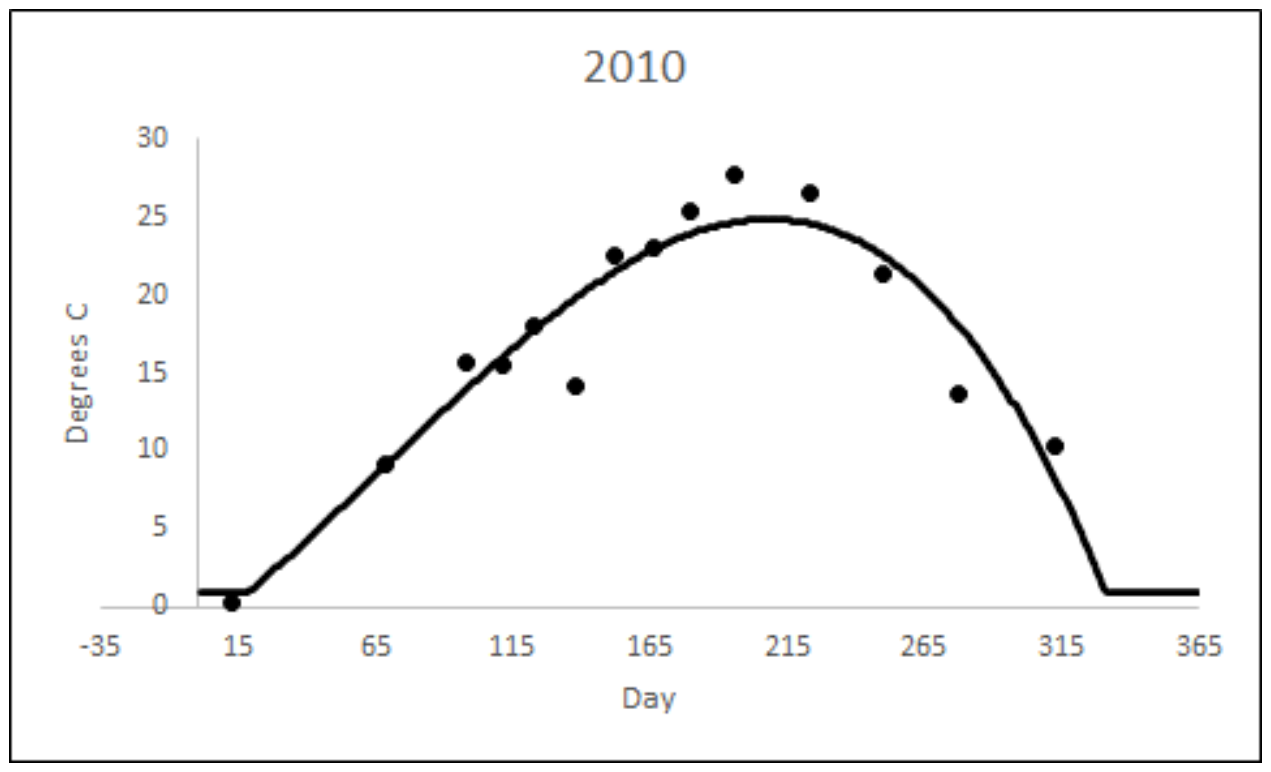

Figure 6. Measured values for nitrate (a lower limit for modeled DIN) reported for 2010 in the La Grange Pool.

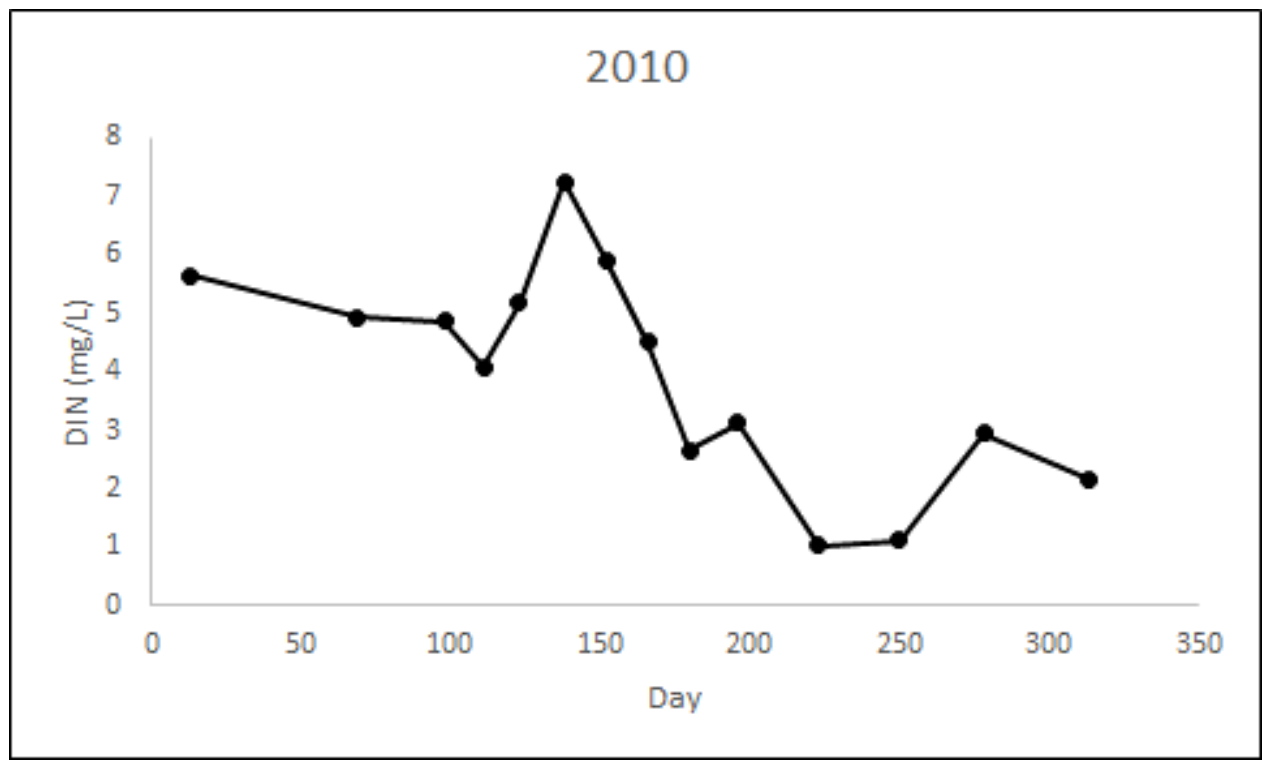


Figure 7. Measured values for soluble reactive $P$ (a proxy for modeled DIP) reported for 2010 in the La Grange Pool.

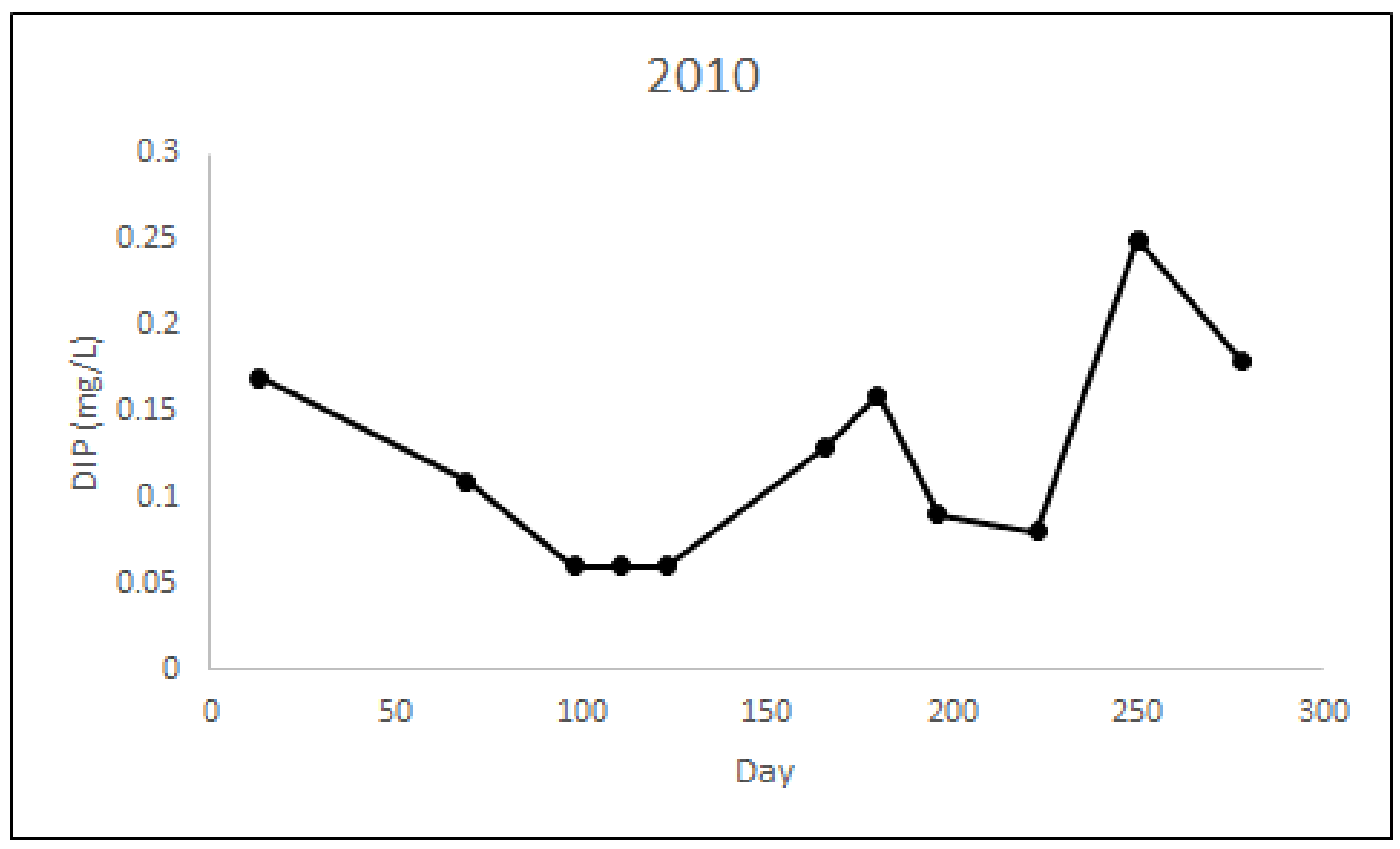

Figure 8. Measured values for total suspended solids (TSS) reported for 2010 in the La Grange Pool.

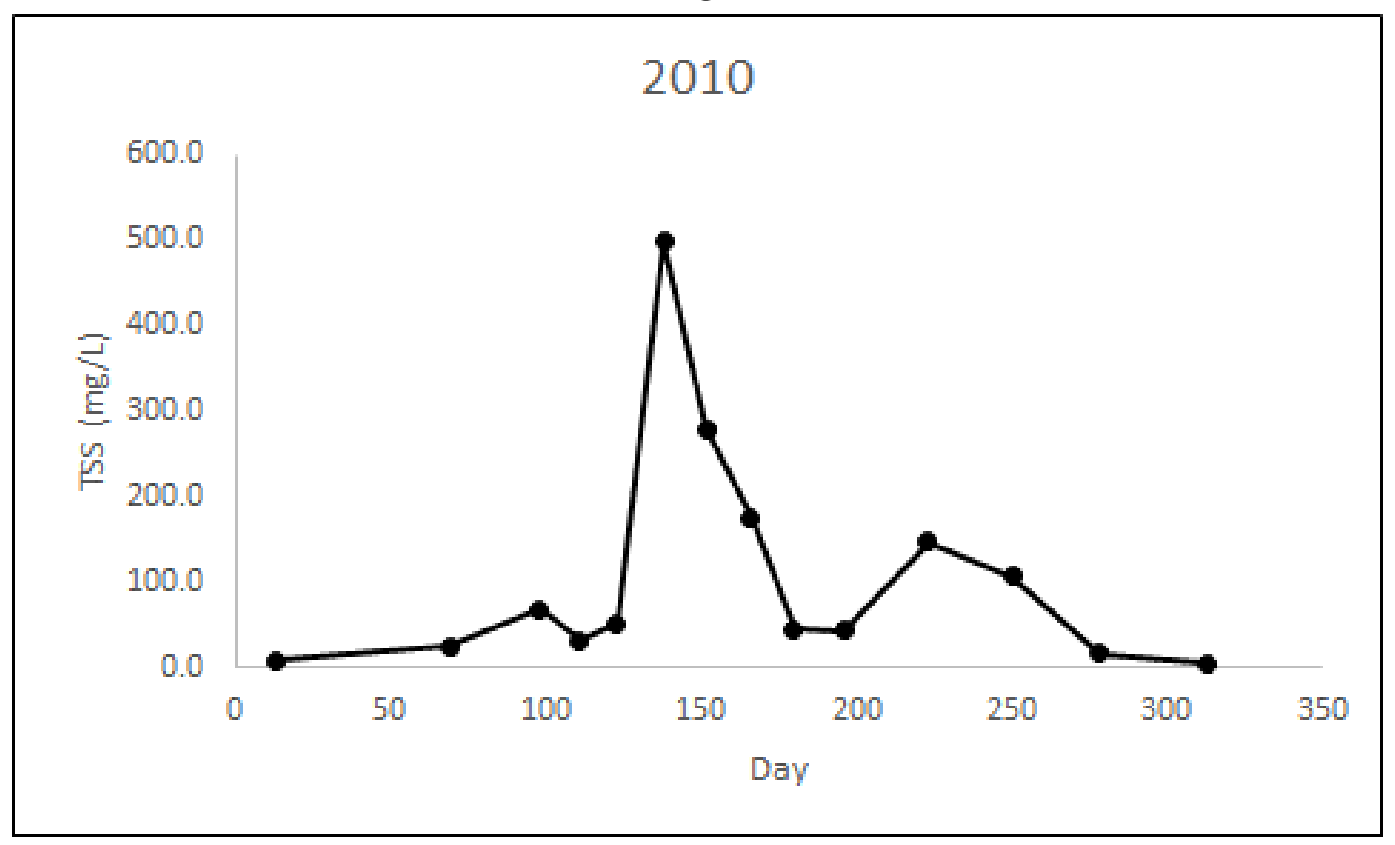

\subsubsection{Modeled nutrient dynamics}

The CASM-SL was modified from previous standard CASM versions (e.g., Bartell et al. 2010b) to provide more detailed accounting of nutrient (,$N$, and P) dynamics for the modeled spatial elements and associated food web structures to more realistically simulate the ecological effects of nutrient 
transport for Sangamon River baseline conditions and the five L\&DD management alternatives.

\subsubsection{Carbon}

Carbon mass is the fundamental unit used by the CASM-SL to simulate standing stock biomass (e.g., $\mathrm{g} \mathrm{C} / \mathrm{m}^{2}$ ) or rates of daily and annual net productivity (e.g., g C/m²/day, g C/m²/year). The model also computes $\mathrm{C}$ sequestered annually (metric tons) in the form of total annual new biomass of primary producers and settled POC. POC is added daily to each modeled segment as an allochthonous (external) input. POC is also produced within the CASM-SL via egestion of prey biomass by predators and natural mortality for all modeled populations of producers, consumers, and decomposers. DOC is produced internally in the CASM-SL through excretion by fish and invertebrates and the decomposition of POC.

\subsubsection{Nitrogen}

Previous versions of the CASM have included daily external inputs of DIN to each spatial segment and depth layer (e.g., Bartell 2017; Bartell et al. 2010a,b). DIN is also simulated internally through excretion by invertebrates and fish, as well as by decomposition and remineralization of detritus.

A major change to modeled formulations for $\mathrm{N}$ included the addition of terms for nitrification and denitrification. Nitrification is a two-step chemical oxidation of $\mathrm{NH}_{4}+$ to $\mathrm{NO}_{3}$ - under aerobic conditions. Houser and Richardson (2010) summarize rates of nitrification characteristic of main channel, backwater, and impounded areas in the UMR (e.g., Navigation Pool 8).

Derivation of CASM-SL parameter values for denitrification was guided by values measured for littoral areas for Lake Shelbyville in the Kaskaskia River (Illinois) watershed (David et al. 2006). Values of potential and ambient denitrification have also been provided for Pool 8 (Houser and Richardson 2010).

The CASM-SL was also adapted to better describe and account for nutrient processing and accumulation by modeled food web constituents, particularly for populations of SAV and emergent or terrestrial plants. For example, Peck and Smart (1986) quantified the production and cellular N 
and P content for five species of SAV (Sagittaria rigida, S. latifolia, Nelumbo, Nymphaea tuberosa, and Certaophyllum demersum in Lake Onalaska (Pool 7). The results in Table 3 of Peck and Smart (1986) were used as initial values to calibrate growth and describe $\mathrm{N}$ and $\mathrm{P}$ accumulation by modeled SAV.

\subsubsection{Phosphorous}

Analogous to DIN, DIP is provided daily as an external P source to each spatial segment and depth layer (e.g., Bartell 2017; Bartell et al. 2010a, b). DIP is also produced internal to the model through the process of excretion by consumer populations and through decomposition of suspended and settled detritus. No modifications were made to the CASMSL with regard to internal DIP cycling.

\subsubsection{Dissolved silica}

The CASM provides the capability for external loading and internal cycling of dissolved silica in relation to the growth dynamics of diatom populations (i.e., phytoplankton, periphyton). However, the absence of readily obtainable data describing silica in the Sangamon River resulted in an assumption that silica was not a limiting factor for diatom growth in the CASM-SL.

\subsection{Model application}

This section describes the application of the CASM-SL to evaluate the possible outcomes of proposed L\&DD management alternatives.

\subsubsection{Integration of HEC-RAS results with the CASM-SL}

The HEC-RAS was calibrated to flood events during the months of December 2016 and January 2017. However, these months represent environmentally challenging conditions (i.e., Illinois winter) for examining the ecological outcomes of the five proposed L\&DD management alternatives. To more usefully evaluate the alternatives, the results for sediment dynamics and land cover change summarized for the five alternatives (Table 1) were used to construct corresponding nutrient $(\mathrm{N}$ and P) loading scenarios for a similar, but hypothetical flood event superimposed on the late-spring and early-summer baseline Sangamon environmental conditions developed for 2010 (i.e., Figure 3, Figure 5). 
The 2-month flood event was defined for CASM-SL model days 125-188 (May 5 - June 10). This period includes the period of peak discharge (Figure 4) and maximum TSS (Figure 8) in the 2010 data. Figure 5 shows that this period also coincides with the onset of warmer water temperatures $\left(\sim 18-24{ }^{\circ} \mathrm{C}\right)$ associated with the seasonal high values of photosynthesis and consumption rates (i.e., high producer and consumer growth potential). This period importantly maps onto the seasonal peak and subsequent rapidly diminishing concentrations of DIN (Figure 6) and a period of low, but increasing concentrations of DIP (Figure 7). These combined modeled conditions of high growth potential and low nutrient concentrations provided the CASM-SL ideal conditions to characterize the ecological outcomes of nutrient transport and loading for the five L\&DD management alternatives. The modeled effects of flood-related nutrient enrichment should be more evident if nutrients are added during a period of higher growth potential and possible nutrient limitation, compared to other seasons where nutrient concentrations are higher and growth is constrained by other factors (e.g., light and temperature - that is, winter conditions [Alberts et al. 2016]).

\subsubsection{Nutrient transport}

The approach for implementing the hypothetical flood event and the responses in nutrient dynamics was to construct daily DIN and DIP loading rates for each of the five L\&DD alternatives. Instead of directly using the HEC-RAS output files to develop input files of flows and sediments to the CASM-SL, this initial proof of principle application translated the overbank sediment retention to corresponding nutrient loading rates by assuming a constant daily sediment retention rate $(\mathrm{kg}$ sediments/day) over the 62-day period defined by total mass of retained sediments for each alternative. The mass of sediments was converted to an approximate corresponding volume of water ( $\mathrm{m} 3 /$ day) by dividing the sediment loading rate by the concentration of sediments in water, which was assumed equal to a representative TSS concentration $\left(100 \mathrm{~g} / \mathrm{m}^{3}\right)$ for this period (Figure 8). This simple computation also assumes that the density of particles that constitute the TSS are essentially identical to those that make up the overbank sediments. Differences between the composition (e.g., sand, silt, and clays) of retained sediments and TSS might bias the estimates of water volumes for each alternative. However, the bias would be consistent across all alternatives and would not influence the comparison of these proposed management actions. The resulting number converted to liters (L)/day of water was multiplied by 
12.0 $\mathrm{mg} \mathrm{N} / \mathrm{L}$ and $0.03 \mathrm{mg} \mathrm{P} / \mathrm{L}$ (David et al. 2006) to generate L\&DD alternative-specific DIN and DIP daily loads. The David et al. (2006) N and $\mathrm{P}$ concentrations are characteristic of high flow events in the Kaskaskia, IL, watershed. These values were the geographically closest available high-flow $\mathrm{N}$ and $\mathrm{P}$ concentrations and were therefore selected for this initial modeling effort. The resulting constant daily loads were added to the baseline DIN and DIP values for modeled days 125-188 for each modeled alternative (Table 2).

Table 2. Estimated DIN and DIP daily concentrations for each modeled alternative daily loadings.

\begin{tabular}{|c|c|c|}
\hline & \multicolumn{2}{|c|}{ Concentration (mg/l) } \\
\hline L\&DD Alternative & DIN & DIP \\
\hline 1A & 0.626 & 0.0157 \\
\hline 1B & 0.656 & 0.0164 \\
\hline 2 & 0.105 & 0.0026 \\
\hline $3 \mathrm{~A}$ & 5.980 & 0.1495 \\
\hline $3 \mathrm{~B}$ & 16.151 & 0.4037 \\
\hline
\end{tabular}

This approach permits the CASM-SL to quantify the direct populationspecific responses of aquatic plants to nutrient enrichment and the potential propagation of changes in plant productivity throughout the modeled food web (i.e., trophic cascade), including invertebrates and fish. These responses reflect changes in habitat quality and are modeled at the resolution of $\mathrm{g} \mathrm{C} / \mathrm{m}^{2} /$ day (either as standing stock biomass or net productivity). The daily model results for the 62-day simulation period for standing stock and net productivity are also summarized annually by the model for each population, life-stage, and spatial segment.

\subsubsection{Land cover changes}

The percentage changes in land cover for agricultural conversion and connection of forest, wetlands, and aquatic areas were computed from the acreage listed in Theiling et al. (2018) and used to modify the baseline (Table 3). 
Table 3. Percentage changes in land cover computed from Theiling et al. (2018).

\begin{tabular}{|l|c|c|c|c|}
\hline & \multicolumn{4}{|c|}{ Land Cover Type } \\
\hline L\&DD Alternative & Agriculture & Wetlands & Forest & Open Water \\
\hline 1A & 0 & 0 & 0 & 0 \\
\hline 1B & 84.8 & 0.48 & 14.1 & 0.66 \\
\hline 2 & 37.8 & 3.12 & 49.1 & 4.96 \\
\hline 3A & 0 & 0 & 0 & 0 \\
\hline 3B & 95.3 & 0.07 & 4.68 & 0 \\
\hline
\end{tabular}

The resulting four modified land covers $\left(\mathrm{m}^{2}\right)$ for each alternative are used to multiply either biomass or net productivity for the populations associated with each land cover to estimate total biomass or net productivity for the cover type and the entire model segment. Segment totals are summed across all five segments to compute a system-wide total of standing stock biomass or net productivity for each population.

As a further initial simplifying assumption, land cover percentages estimated for the river reach (Segment 1) and the Sanganois Conservation Area (Segment 2) are assumed unchanged by the L\&DD management alternatives. Additionally, consistent with the modeling objectives defined for the CASM-SL, converted agricultural lands were opened for occupation and growth for barnyard grass, chufa, and smartweed, as well as cattails, arrowhead, and common reed.

\subsubsection{Ecosystem services}

The CASM-SL computes ecosystem services in the form of food/fiber, water quality indicators, and ecosystem function. Food/fiber includes aggregate biomass (or productivity) of select aquatic plants (e.g., Phragmites), edible invertebrates (e.g., bivalves, crayfish), and panfish , including bluegill (L. macrochirus), black crappie (Pomoxis nigromaculatus), and black bullhead (Ameiurus melas) - all included in the modeled food web. A recreational indicator can be computed as the aggregate biomass (or productivity) of modeled sportfish populations, for example, largemouth bass (Micropterus salmoides).

Water quality ecosystem service indicators include total chlorophyll, dissolved oxygen, and Secchi depth (water clarity). Biomass of modeled cyanobacteria (i.e., blue-green algae) can also be interpreted as an 
indicator of water quality. Excessive increases in blue-green algae biomass could be described as an ecosystem disservice in the context of harmful algal blooms.

Ecosystem function modeled by the CASM-SL includes total system (i.e., summed over all spatial segments) values of oxygen production, C sequestered in the form of biomass and sedimented POC, and accumulated (not recycled) $\mathrm{N}$ and $\mathrm{P}$.

Selected ecosystem services were computed for the baseline CASM-SL and compared to corresponding service values for all five L\&DD management alternatives. 


\section{CASM-SL Application and Calibration}

The CASM-SL was calibrated to define baseline conditions and then used to simulate outcomes of hydrodynamic and nutrient transport constructed for the five levee alternatives described in Theiling et al. (2018). The outcomes of the management alternatives were computed as the difference between simulated baseline productivity and ecosystem services compared to those of each simulated management alternative.

The calibration of the CASM-SL was performed by systematically adjusting the bioenergetics parameters and initial biomass values in 1-year simulations to match observed values for populations (described in following paragraphs) in the Sangamon or Illinois Rivers and adjacent landscapes or from similar ecosystems. Qualitative calibration efforts were guided by published descriptions for specific populations included in the modeled food web, as well as for relevant aquatic guilds or communities (e.g., Anderson and Day 1986; Barko et al. 2004; Chick et al. 2006, 2005; Coon et al. 1997; Koel and Sparks 2002; Madejczyk et al. 1998; Parker 2014; Peck and Smart 1986; Pegg and McClelland 2004; Sampson et al. 2009).

For example, Peck and Smart (1986) reported SAV daily production as $1-$ $5.3 \mathrm{~g} \mathrm{C} / \mathrm{m}^{2}$ for Nymphaea and $0.4-2.5 \mathrm{~g} \mathrm{C} / \mathrm{m}^{2}$ for Sagittaria in the Upper Mississippi River. The CASM-SL overestimates Nymphaea production $\left(\right.$ mean $\left.=19.5 \mathrm{~g} \mathrm{C} / \mathrm{m}^{2}\right)$. Modeled values of Sagittaria production ranged from $0-0.4 \mathrm{~g} \mathrm{C} / \mathrm{m}^{2}$. These reported values compare favorably with the modeled production of two other SAV, Vallisneria $\left(\right.$ mean $=6.15 \mathrm{~g} \mathrm{C} / \mathrm{m}^{2}$ ) and Ceratophyllum (mean $=1.72 \mathrm{~g} \mathrm{C} / \mathrm{m}^{2}$ ). It is recognized that the values reported by Peck and Smart (1986) for clear water systems are likely overestimates of realistic values for the Illinois River. However, the initial calibration results suggest that modeled SAV productivities, while perhaps biased high, are likely within an order of magnitude of values representative of the Illinois.

Sampson et al. (2009) reported the relative abundance of zooplankton populations in the Illinois River. They observed the zooplankton to be dominated by rotifers $(2,000-6,000 / L)$, followed by adult copepods (10$5 \mathrm{O} / \mathrm{L}$ ), and cladocerans (2-8/L). Without values of individual organism sizes, it was not possible to convert the densities to C. However, the CASM-SL values of zooplankton average daily production are similar in relative abundance with microzooplankton and rotifers $\left(6.5 \mathrm{~g} \mathrm{C} / \mathrm{m}^{3}\right)$ 
dominating the modeled zooplankton, followed by copepods $\left(0.57 \mathrm{~g} \mathrm{C} / \mathrm{m}^{3}\right)$ and cladocerans $\left(0.56 \mathrm{~g} \mathrm{C} / \mathrm{m}^{3}\right)$.

The biomass of benthic invertebrates characteristic of naturally flooded Mississippi floodplain forests averaged $1.8 \mathrm{~g} \mathrm{C} / \mathrm{m}^{2}$ (range 0.16 - 4.23) based on the analysis by Wehrle et al. (1995). These values compare with CASM-SL modeled baseline average biomass values of $3.83 \mathrm{~g} \mathrm{C} / \mathrm{m}^{2}$ (range $\mathrm{o}-7.69$ ) and $4.38 \mathrm{~g} \mathrm{C} / \mathrm{m}^{2}$ (range $\mathrm{o}-8.60$ ) for chironomids and oligochaetes. Anderson and Day (1986) similarly underscored the potential for high biomass values of benthic invertebrates in channel borders and side-channels in floodplain ecosystems. The CASM-SL simulated average daily production of bivalves as $0.645 \mathrm{~g} \mathrm{C} / \mathrm{m}^{2}$ (range $\mathrm{o}-$ 1.06), which compare with the value of $0.22 \mathrm{~g} \mathrm{C} / \mathrm{m}^{2}$ reported for mussels in the Upper Mississippi River (Coon et al. 1977).

Fish abundance data for the Upper Mississippi River (Barko et al. 2004) and the LaGrange Pool of the Illinois River (Chick et al. 2006; Koel and Sparks 2002) were used in the initial calibration of the CASM-SL. Productivity estimates have not yet been developed. However, comparison of the rank orders of measured and modeled fish populations suggests that the model provides at least a qualitatively realistic characterization of an assemblage relevant to the Illinois River (Figure 9). The measured and modeled rank orders of importance are positively related, although considerable scatter remains to be addressed in future calibration efforts. 
Figure 9. Comparison of modeled and measured rank order of relative abundance for 14 fish populations modeled by the CASM-SL (based on data provided in Barko et al. [2004]).

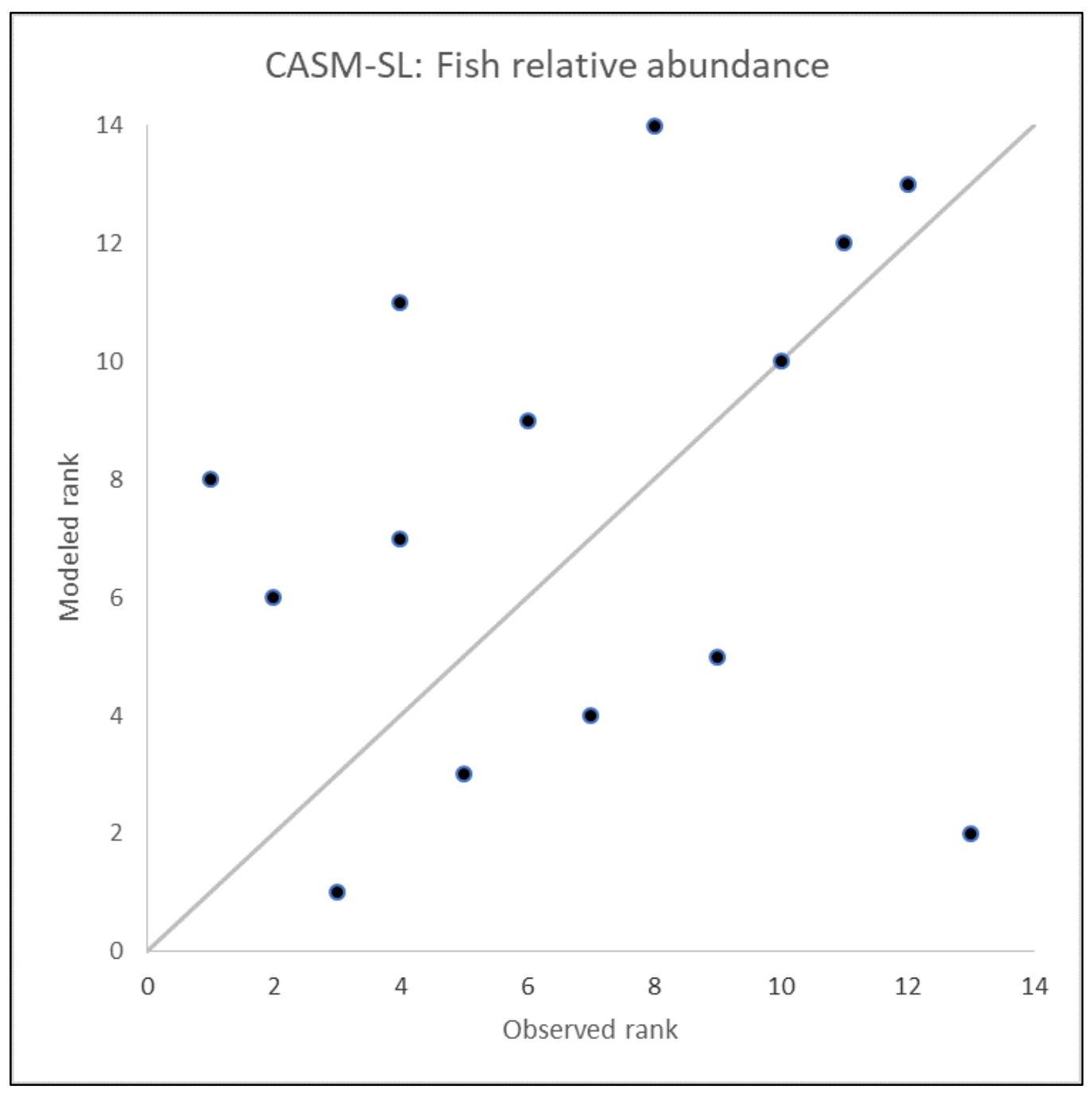

The initial calibration results indicate that it is possible to use the CASMSL to evaluate the relative ecological risks and benefits anticipated for the levee management alternatives. While there is undoubted bias introduced into the present baseline simulation (e.g., incomplete ecosystem understanding; relatively sparse data; extrapolations across similar, but not identical systems), such bias will remain essentially constant and largely factor-out in evaluations of the alternatives. Calibration of CASMSL should be fairly viewed as a work in progress, with the current baseline offered as proof in principle of the overall model development in relation to the stated modeling objectives. 


\section{Results}

The CASM-SL generates daily values of biomass and net productivity for each modeled population in each spatial segment. Selected results are presented to demonstrate the ability of this preliminary model to characterize the possible ecological outcomes of the proposed L\&DD management alternatives consistent with the overall modeling objectives.

\subsection{Biomass responses}

The biomass of modeled submerged aquatic vegetation (Figure 10), and the productivity of selected macroinvertebrates (Figure 11) and fish (Figure 12) are presented as examples of the seasonal production dynamics generated by the initial baseline CASM-SL. The modeled effects of the five management actions are normalized to the baseline. Bias or inaccuracy in describing the seasonal production dynamics of the modeled population associated with the baseline are also included in the simulations of the management alternatives. Therefore, the normalized differences can inform the evaluation of management alternatives in a relative sense, while further refinements to the baseline calibration are implemented to reduce model baseline bias in absolute terms.

Figure 10 demonstrates the ability of the CASM-SL to produce seasonal patterns of growth for modeled aquatic plant populations. The nearshore habitat of the Sangamon River segment is dominated by Nymphaea with lesser contributions to modeled macrophyte community biomass from Vallisneria and Ceratophyllum. Potamogeton is comparatively less abundant in the modeled aquatic macrophyte community.

The baseline macroinvertebrate community modeled by the CASM-SL is dominated by oligochaetes, chironomid larvae, and caddisflies (Figure 11). Bivalves and amphipods constitute the remainder of modeled benthic macroinvertebrate community.

Figure 12 illustrates the modeled seasonal patterns of daily net productivity for selected CASM-SL fish populations. Black bullheads and bluegills are highly productive with lesser contributions from shortnose gar and smallmouth buffalo. 
The CASM-SL demonstrates the ability to simulate increased productivity of modeled macrophytes in relation to nutrient loading to segment 5 (Oakford L\&DD) for management Alternative 3B (Figure 13). (Note that the break in the plot for days 246-250 results from zero net productivity associated with modeled depths going to zero for those days, based on the interpolations of 2010 flow data.) These productivity values are applied to macrophytes in reconnected wetlands and open water habitats generated by this management action.

Figure 10. Baseline biomass for modeled submerged aquatic vegetation in the Sangamon River segment for the baseline condition.

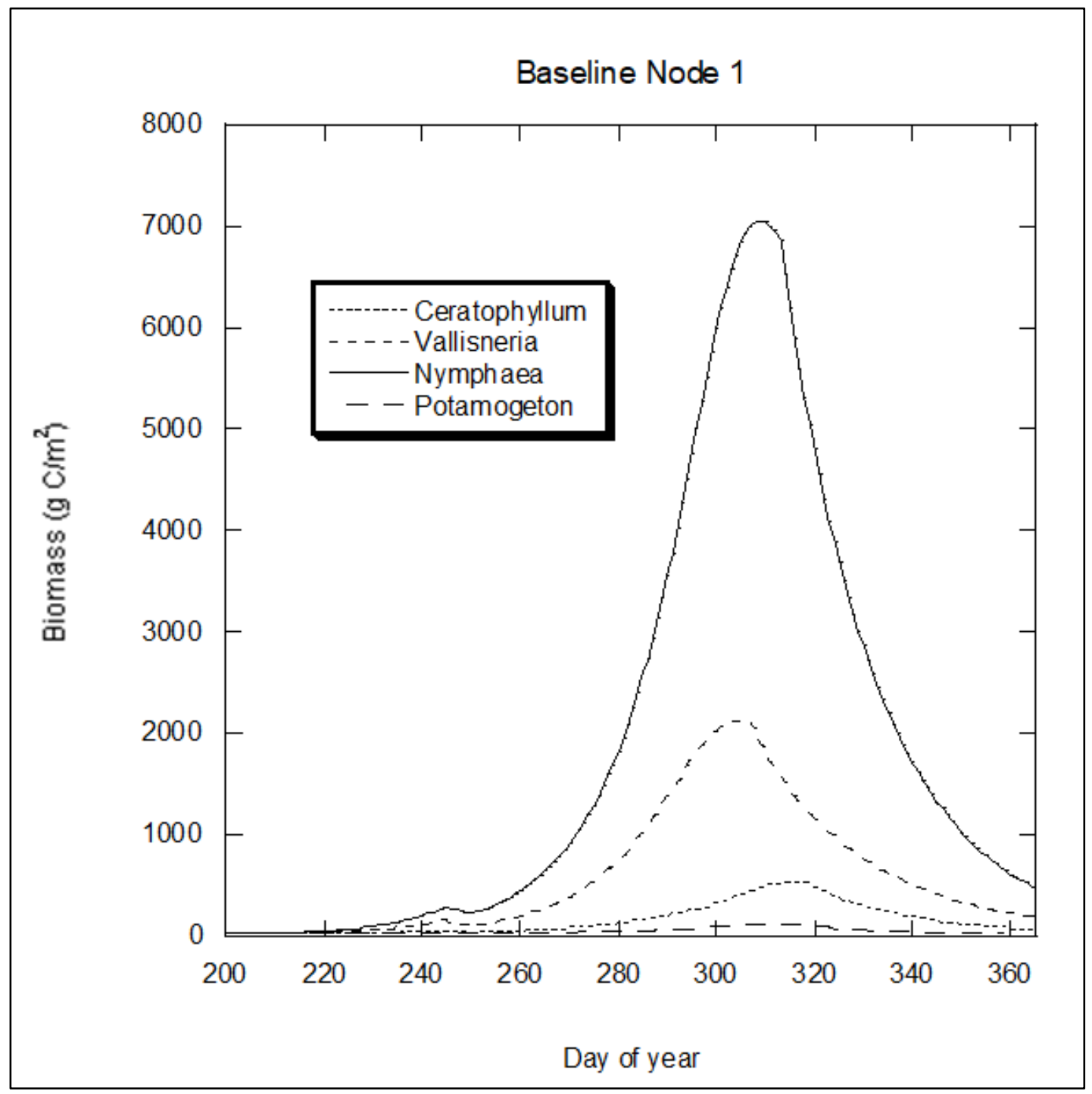


Figure 11. Baseline daily net productivity for modeled macroinvertebrates populations in the Sangamon River segment.

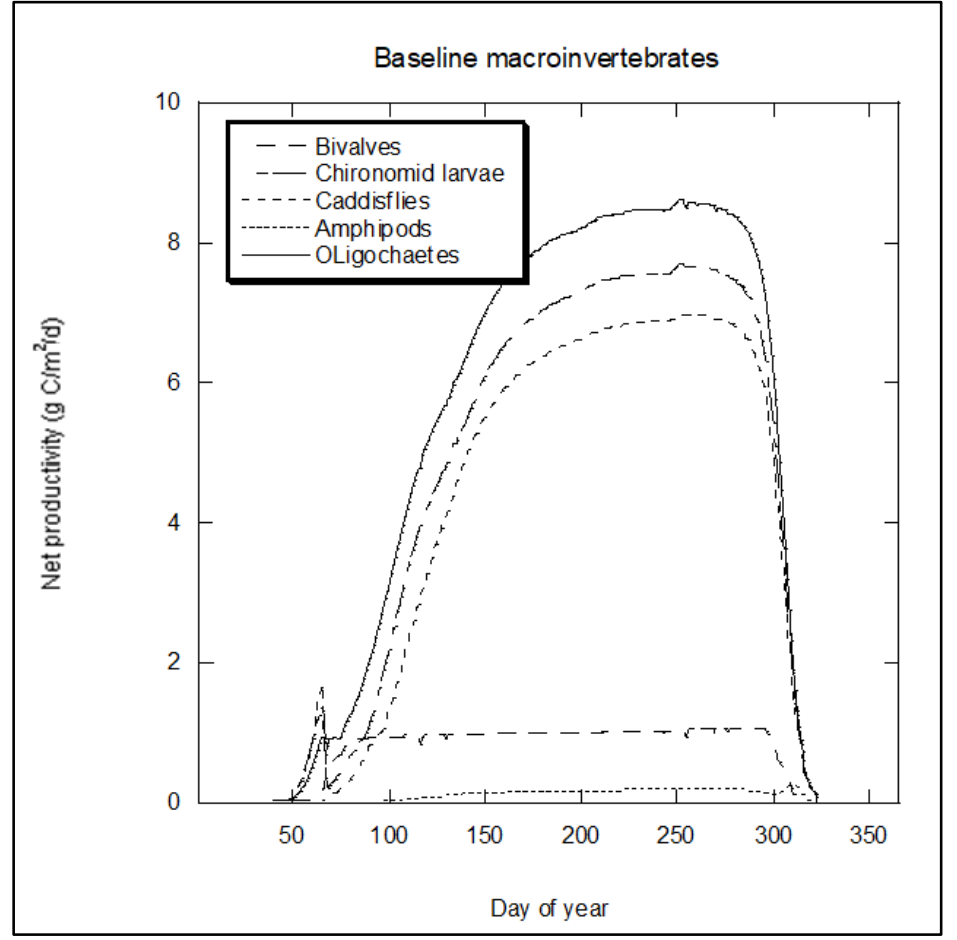

Figure 12. Baseline daily net productivity of selected modeled fish populations in the Sangamon River segment.

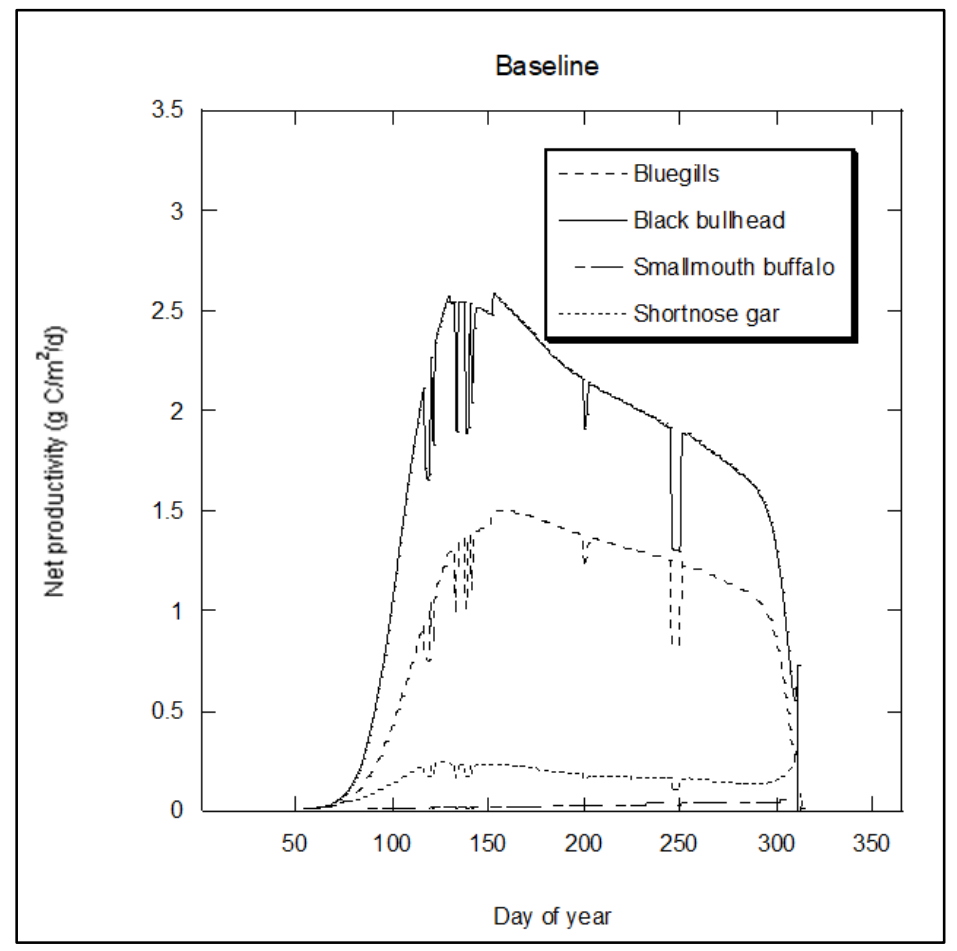


Figure 13. Daily net productivity of modeled aquatic vegetation in the Oakford L\&DD for Alternative 3B.

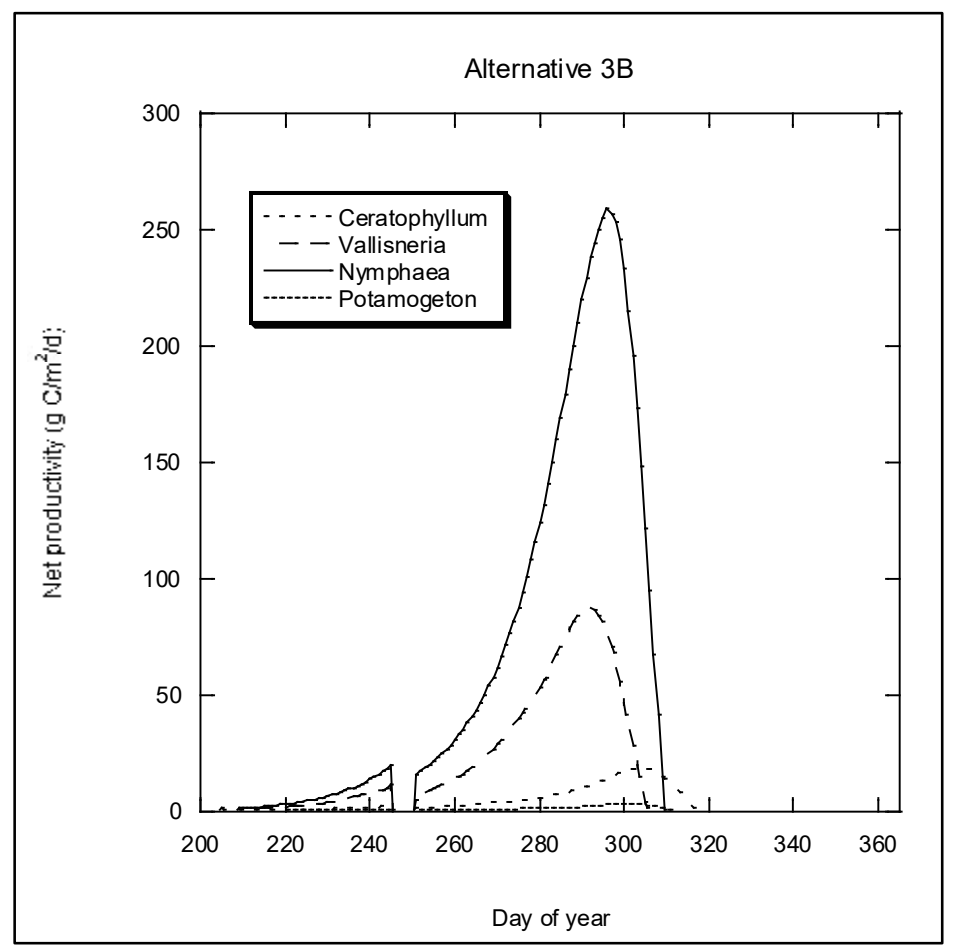

\subsection{Alternative comparison}

Productivity in the modeled spatial segments can be used to evaluate and compare the potential outcomes of the modeled management alternatives (e.g., Table 4). The results indicate that for the Oakford L\&DD, Alternative $3^{\mathrm{B}}$ provides greater rates of productivity for the four modeled macrophyte populations as the result of nutrient loadings to segment 5 derived for $3 \mathrm{~B}$.

Table 4. Annual net productivity ( $\mathrm{g} \mathrm{C} / \mathrm{m}^{2} / \mathrm{yr}$ ) for modeled SAV in segment 5 (Oakford L\&DD). Baseline (1) refers to segment 1 (Sangamon River) baseline productivity.

\begin{tabular}{|c|c|c|c|c|}
\hline & \multicolumn{4}{|c|}{ Annual Net Productivity (g C/m²/yr) } \\
\hline L\&DD Alternative & Ceratophyllum & Vallisneria & Nymphaea & Potamogeton \\
\hline $\begin{array}{c}\text { Baseline } \\
\text { (Segment 1) }\end{array}$ & 626 & 2,240 & 7,120 & 133 \\
\hline 1A & 16 & 42 & 43 & 8 \\
\hline 1B & 18 & 50 & 6 & 8 \\
\hline 2 & 0 & 0 & 0 & 0 \\
\hline 3A & 0 & 0 & 0 & 0 \\
\hline 3B & 61 & 249 & 719 & 140 \\
\hline
\end{tabular}


The spatial segment summaries tallied the modeled productivity of barnyard grass, chufa, smartweed, cattails, and arrowhead in relation to conversion of agricultural land cover to more natural areas and reconnection with wetlands (Table 5). Alternative $3 \mathrm{~B}$ shows the greatest potential for increased productivity of these modeled plants for the Oakford L\&DD. Segment 3 (Clear Lake) is assumed not affected by Alternatives $3 \mathrm{~A}$ or $3 \mathrm{~B}$. Alternative $3 \mathrm{~B}$ results in high productivity of barnyard grass, chufa, and smartweed in the Oakford L\&DD compared to Alternative $1 \mathrm{~B}$, but $1 \mathrm{~B}$ demonstrates greater productivity of cattails and arrowhead for Clear Lake (Segment 3).

Table 5. Annual net productivity ( $\mathrm{g} \mathrm{C} / \mathrm{m}^{2} / \mathrm{y}$ ) for modeled emergent aquatic plants in segment 3 (Clear Lake L\&DD) and segment 5 (Oakford L\&DD) for 3A and 3B.

\begin{tabular}{|l|c|c|c|c|}
\hline & \multicolumn{4}{|c|}{ Above-Ground Annual Net Productivity (g C/m²/yr) } \\
\hline L\&DD Alternative & $\begin{array}{c}\text { Barnyard } \\
\text { grass }\end{array}$ & Chufa & Smartweed & Cattails \\
\hline Baseline (Segment 1) & 0 & 0 & 0 & 9 \\
\hline 1A (Segment 3) & 0 & 0 & 0 & 9 \\
\hline 1B (Segment 3) & 0 & 0 & 0 & 120 \\
\hline 2 (Segment 4) & 0 & 0 & 0 & 9 \\
\hline 3A (Segment 3) & 0 & 0 & 0 & 9 \\
\hline 3B (Segment 3) & 0 & 0 & 0 & 9 \\
\hline 3A (Segment 5) & 0 & 0 & 0 & 26 \\
\hline 3B (Segment 5) & 686 & 317 & 246 & 30 \\
\hline
\end{tabular}

\subsection{Total system net productivity}

Summing the modeled effects of the simulated management actions across all spatial segments provides a system-scale description of the potential outcomes of the five alternatives compared to the baseline (Table 6). The percentage changes in productivity for selected plant guilds, mayflies, and common carp suggest that Alternative $3 \mathrm{~B}$ provides the greatest ecological benefits (and perhaps risk), although $1 \mathrm{~B}$ suggest higher relative productivity of emergent aquatic plants. 
Table 6. Relative (\%) changes in total system productivity for selected populations compared to baseline simulation.

\begin{tabular}{|c|c|c|c|c|}
\hline & \multicolumn{4}{|c|}{ Percentage Change from Baseline Simulation } \\
\hline L\&DD Alternative & SAV & Emergent plants & Mayflies & Common carp \\
\hline 1A & 1 & 0 & 0 & 0 \\
\hline 1B & 1 & 35 & 2 & 1 \\
\hline 2 & 0 & 0 & 0 & 2 \\
\hline 3A & 19 & 0 & 2 & 5 \\
\hline 3B & 28 & 22 & 7 & 8 \\
\hline
\end{tabular}

The mayflies and common carp were selected as representative macroinvertebrates and fish populations because they occur in the project area and were already incorporated into the base CASM. Inspection of system-level percentage changes in productivity for the remaining modeled populations of invertebrates and fish indicated a consistent $1 \%$ to $5 \%$ increases in relative productivity for Alternative $3 \mathrm{~B}$. Changes on the order of zero to $3 \%$ were observed for these populations across the other management alternatives.

The results presented in Table 6 demonstrate that the modeled nutrient loadings provided by the simulated flood translated directly into increased aquatic plant biomass. Phytoplankton and periphyton productivity also increased by $3 \%$ and $6 \%$ for Alternative $3 \mathrm{~B}$. These direct changes in primary productivity translated into corresponding modeled changes in the productivity of modeled populations of zooplankton, other macroinvertebrates, and fish.

Inspection of the total system productivity results appears as an efficient approach for rapidly evaluating and comparing the five management alternatives in term of ecological productivity across the modeled food web.

\subsection{Ecosystem services}

The results produced by the CASM-SL were used to characterize the implications of the proposed management alternatives on recreation and food production for human use. The model results indicate that Alternative $1 \mathrm{~B}$ provides the greatest relative benefit (6\%) of increased productivity of largemouth bass, which could be used as an indicator of increased potential for sport fishing. The results summarized in Table 7 similarly show Alternative $1 \mathrm{~B}$ as comparatively better at providing food in the form of 
edible mussels, and channel catfish. Alternative $3 \mathrm{~B}$ produced the greatest relative increase in crayfish production.

Table 7. Relative (\%) change in annual productivity of selected edible invertebrates and panfish compared to the baseline simulation.

\begin{tabular}{|c|c|c|c|c|}
\hline & \multicolumn{4}{|c|}{ Percentage Change from Baseline Simulation } \\
\hline \multirow{2}{*}{ L\&DD Alternative } & Bivalves & Crayfish & $\begin{array}{c}\text { Largemouth } \\
\text { bass }\end{array}$ & Channel Catfish \\
\hline $1 \mathrm{~A}$ & 0 & 0 & 0 & 0 \\
\hline $1 \mathrm{~B}$ & 6 & 1 & 6 & 8 \\
\hline 2 & 2 & 0 & 2 & 1 \\
\hline $3 \mathrm{~A}$ & -1 & 0 & 0 & 0 \\
\hline $3 \mathrm{~B}$ & 1 & 5 & 1 & 1 \\
\hline
\end{tabular}

The internal tracking of nutrients (N, P, dissolved silica), dissolved oxygen, and $\mathrm{C}$ permits the CASM-SL to characterize ecosystem function services associated with the L\&DD management alternatives (Table 8). In contrast to the metrics based on biological productivity, the relative ecosystem function responses to management suggest that Alternatives $3 \mathrm{~A}$ and $3 \mathrm{~B}$ provide the greatest relative change. Alternative $1 \mathrm{~A}$ remains a better choice than the Alternatives $1 \mathrm{~B}$ and 2 . Both $3 \mathrm{~A}$ and $3 \mathrm{~B}$ are similar in terms of relative increases in sequestered $\mathrm{C}$. The identical results for percentage changes in accumulated $\mathrm{N}$ and $\mathrm{P}$ compared to baseline are likely caused by the constant stoichiometry between $\mathrm{N}$ and $\mathrm{P}$ assumed in the model.

Table 8. Relative (\%) ecosystem function performance compared to baseline simulation.

\begin{tabular}{|c|c|c|c|c|}
\hline & \multicolumn{4}{|c|}{ Percentage Change from Baseline Simulation } \\
\hline L\&DD Alternative & 02 Produced & C Sequestered & N Accumulated & P Accumulated \\
\hline $1 \mathrm{~A}$ & 4 & 2 & 2 & 2 \\
\hline $1 \mathrm{~B}$ & 1 & 2 & -2 & -2 \\
\hline 2 & -1 & 0 & -1 & -1 \\
\hline $3 \mathrm{~A}$ & 29 & 22 & 25 & 25 \\
\hline $3 \mathrm{~B}$ & 7 & 27 & 5 & 5 \\
\hline
\end{tabular}




\section{Discussion}

The CASM application presented in this report demonstrates the potential applicability of this tool to inform levee setback decisions. The model could be applied to assess or isolate the impacts of model parameters related to environmental input files, baseline bioenergetics parameters, diet preferences, and/or habitat quality requirement of the modeled populations. Importantly, the impacts of stressors (e.g., increased temperature, nutrients, hypoxia) can be assessed individually or in combination using the CASM-SL.

The current CASM-SL was created as a proof-of-concept to demonstrate how CASM could provide quantitative descriptions of the nutrient and food web impacts associated with levee setbacks and modifications. CASM (and CASM-SL) should be able to provide more detailed results with the addition of more site-specific data (e.g., water quality, population biomass, land cover). Establishing mechanistic linkages between hydraulics and hydrology models and CASM, especially at more refined spatial scales, could improve the broad applicability of CASM and the confidence in the results by providing for more realistic simulations. These improved model linkages could also pave the way for future improvements such as looking at year-to-year variability or exploring the implications of numerical sensitivity and model uncertainty on projected outcomes of L\&DD management alternatives.

The development of the CASM-SL encountered several challenges that influence its current utility. The model did not directly use the output files from HEC-RAS to construct hydrodynamic and sediment loading input files specific to baseline and the management alternatives, given the winter scenario. This lack of a direct connection between the two models (CASMSL and HEC-RAS) required reliance on the aggregate results for the alternatives summarized in Theiling et al. (2018) and corresponding assumptions to translate overbank sediment volumes to nutrient loading rates. This approach also required the simplification that management alternatives mapped spatially to only one spatial segment that referenced the corresponding L\&DD. That is, simulations of Alternative $1 \mathrm{~A}$ and $1 \mathrm{~B}$ could only directly impact segment 3, which represented the Clear Lake L\&DD. System-wide inferences were made from simulations of separate independent simulations. 
The baseline CASM-SL simulation should be interpreted as a work in progress. The modeled productivity and biomass values for the producer and consumer populations appear reasonable in magnitude based on previous version and applications of the CASM (e.g., Bartell et al. 2017, 2013, 2010a, 2010b). However, the seasonality in production for some populations appears shifted later in the modeled year, likely due to the late season increase in DIP based on 2010 data. Future efforts in further CASM-SL development should focus initially on additional calibration. 


\section{Conclusions and Recommendations}

The initial development and application of the CASM-SL demonstrate that it is possible to use a bioenergetics and habitat quality model to provide qualitative descriptions of ecological risks and benefits afforded by levee setbacks and other modifications. The CASM-SL provides a methodology for advancing beyond subjective rankings (e.g., Theiling et al. 2018) of impacts to agricultural lands, natural riparian habitats, and ecosystem services in evaluating outcomes of levee management alternatives.

The CASM-SL suggests that Alternative $3 \mathrm{~B}$ (removal of the Oakford L\&DD levee) would provide the greatest benefits relative to baseline for increased productivity of modeled populations of aquatic plants, invertebrates, and fish. However, Alternative $3 \mathrm{~B}$ ranked second behind 3A (addition of gated inlets to the Oakford L\&DD) for increases in ecosystem services (except for C sequestration).

Despite potential limitations resulting from the current modeling challenges, the logistics of the CASM-SL recommend it as a transparent tool for use in rapid prototype planning with stakeholders. Once an agreed upon baseline simulation is constructed, the evaluation of management alternatives can proceed efficiently, with 1-year simulations taking less than 1 minute on a desktop workstation or professional quality laptop computer. Generated files of model results can be readily opened using commercial spreadsheets for additional analysis, summary, and presentation. 


\section{References}

Alberts, J. M., J. J. Beaulieu, and I. Buffam. 2016. "Watershed Land Use and Seasonal Variation Constrain the Influence of Riparian Canopy Cover on Stream Ecosystem Metabolism.” Ecosystems. DOI: 10.1007/s10021-016-0040-9 (online publication).

Anderson, R. V., and D. M. Day. 1986. "Predictive Quality of Macroinvertebrate-Habitat Associations in Lower Navigation Pools of the Mississippi River." Hydrobiologia 136(1): 101-112.

Barko, V. A., D. P. Herzog, R. A. Hrabik, and J. S. Scheibe. 2004. "Relationship among Fish Assemblages and Main-Channel-Border Physical Habitats in the Unimpounded Upper Mississippi River.” Transactions of the American Fisheries Society 133(2): 371-384.

Bartell, S. M. 2003. "A Framework for Estimating Ecological Risks Posed by Nutrients and Trace Elements in the Patuxent River." Estuaries 26: 385-397.

Bartell, S. M. 2017. SAND-CASM-4D-SC Integrated Model User Manual. Vicksburg, MS: US Army Engineer Research Development Center.

Bartell, S. M., G. Lefebvre, G. Kaminski, M. Carreau, and K. R. Campbell. 1999. “An Ecosystem Model for Assessing Ecological Risks in Québec Rivers, Lakes, and Reservoirs." Ecological Modelling 124: 43-67.

Bartell, S. M., K. R. Campbell, C. M. Lovelock, S. K. Nair, and J. L. Shaw. 2000. "Characterizing Aquatic Ecological Risks from Pesticides Using a Diquat Dibromide Case Study III. Ecological Process Models.” Environmental Toxicology and Chemistry 19: 1441-1453.

Bartell, S. M., S. K. Nair, and Y. Wu. 2010a. Final Report. Evaluation of Chloride Management Alternatives: Application of the Comprehensive Aquatic Ecosystem Model (CASM) to Lake Texoma. US Army Corps of Engineers. Tulsa, OK: Tulsa District.

Bartell, S. M., S. K. Nair, and Y. Wu. 2010b. Mississippi River - Gulf Outlet (MRGO). Revisions to the Comprehensive Aquatic Ecosystem Model (CASM). Preliminary evaluation of proposed freshwater diversions in the vicinity of Violet, Louisiana. US Army Corps of Engineers. New Orleans, LA: New Orleans District.

Bartell, S. M., R. A. Brain, P. Hendley, and S. K. Nair. 2013. "Modeling the Potential Effects of Atrazine on Aquatic Communities in Midwestern Streams." Environmental Toxicology and Chemistry 32: 2402-2411.

Bartell, S. M., S. K. Nair, S. Grant, and R. A. Brain. 2017. "Modeling the Effects of Thiamethoxam on Midwestern Farm Ponds and Emergent Wetlands." Environmental Toxicology and Chemistry 37: 738-754. 
Chick, J. H., B. S. Ickes, M. A. Pegg, V. A. Barko, R. A. Hrabik, and D. P. Herzog. 2005. Spatial Structure and Temporal Variation of Fish Communities in the Upper Mississippi River System. Geological Survey La Crosse, WI, Upper Midwest Environmental Sciences Center.

Chick, J. H., M. A. Pegg, and T. M. Koel. 2006. "Spatial Patterns of Fish Communities in the Upper Mississippi River System: Assessing Fragmentation by Low-Head Dams." River Research and Applications 22(4): 413-427.

Coon, T. G., J. W. Eckblad, and P. M. Trygstad. 1977. "Relative Abundance and Growth of Mussels (Mollusca: Eulamellibranchia) in Pools 8, 9, and 10 of the Mississippi River." Freshwater Biology 7(3): 279-285.

Dahl, T. A., C. H. Theiling, and W. Echevarria. 2017. Overview of Levee Setback Projects and Benefits. ERDC/CHL CHETN-VII-17. Vicksburg, MS: US Army Engineer Research and Development Center. http://dx.doi.org/10.21079/11681/ 22767

David, M. B., L. G. Wall, T. V. Royer, and J. L. Tank. 2006. "Denitrification and the Nitrogenbudget of a Reservoir in an Agricultural Landscape." Ecological Applications 16: 2177-2190.

DeAngelis, D. L., S. M. Bartell, and A. L. Brenkert. 1989. "Effects of Nutrient Cycling and Food Chain Length on Resilience.” American Naturalist 134: 788-805.

Delong, M. D., 2010. "Food Webs and the Upper Mississippi River: Contributions to Our Understanding of Ecosystem Function in Large Rivers." Hydrobiologia 640(1): 89-101.

Eckblad, J. W., N. L. Peterson, K. Ostlie, and A. Temte. 1977. “The Morphometry, Benthos and Sedimentation Rates of a Floodplain Lake in Pool 9 of the Upper Mississippi River." American Midland Naturalist 433-443.

Gergel, S. E., S. R. Carpenter, and E. H. Stanley. 2005. "Do Dams and Levees Impact Nitrogen Cycling? Simulating the Effects of Flood Alterations on Floodplain Denitrification." Global Change Biology 11: 1352-1367.

Hartman, K. J. 2017. "Bioenergetics of Brown Bullhead in a Changing Climate." Transactions of the American Fisheries Society 146(4): 634-644.

Hosner, J. F., and L. S. Minckler. 1963. "Bottomland Hardwood Forests of Southern Illinois--Regeneration and Succession.” Ecology 44(1): 29-41.

Houser, J. N., and W. B. Richardson. 2010. "Nitrogen and Phosphorus in the Upper Mississippi River: Transport, Processing, and Effects on the River Ecosystem." Hydrobiologia 640: 71-88.

Jones, K. E., T. A. Dahl, and Z. P. Corum. 2018. Modeled Sedimentation in the Lower White River Countyline Levee Setback, Washington State: Comparison of $1 D$ (HEC-RAS) and 2D (AdH) Results. ERDC/CHL TR-18-9. Vicksburg, MS: US Army Engineer Research and Development Center.

Karr, J. R., L. A. Toth, and D. R. Dudley. 1985. "Fish Communities of Midwestern Rivers: A History of Degradation." BioScience 35(2): 90-95. 
Kitchell, J. F., D. J. Stewart, and D. Weininger. 1977. "Applications of a Bioenergetics Model to Perch (Perca flavescens) and Walleye (Stizostedion vitreum)." Journal of the Fisheries Research Board of Canada 34: 1922-1935.

Kitchell, J. F., J. F. Koonce, R. V. O’Neill, H. H. Shugart, Jr., J. J. Magnuson, and R. S. Booth. 1974. "Model of Fish Biomass Dynamics." Transactions of the American Fisheries Society 103: 786-798.

Koel, T. M., and R. E. Sparks. 2002. "Historical Patterns of River Stage and Fish Communities as Criteria for Operations of Dams on the Illinois River." River Research and Applications 18(1): 3-19.

Larson, R. S., T. A. Butts, and K. P. Singh. 1994. Water Quality and Habitat Suitability Assessment: Sangamon River between Decatur and Petersburg. ISWSCR-571. Division of Water Resources, Illinois Department of Transportation.

Lubinski, K. S., A. Vooren, G. Farabee, J. Janecek, and S. D. Jackson. 1986. "Common Carp in the Upper Mississippi River.” Hydrobiologia 136(1): 141-153.

Madejczyk, J. C., N. D. Mundahl, and R. M. Lehtinen. 1998. "Fish Assemblages of Natural and Artificial Habitats within the Channel Border of the Upper Mississippi River." The American Midland Naturalist 139(2): 296-310.

McCree, K. J. 1972. "The Action Spectrum, Absorbance and Quantum Yield of Photosynthesis in Crop Plants.” Agricultural and Forest Meteorology 9: 91-216.

Parker, J. 2014. Long-Term Impacts of Water Quality and Climate Variability on Illinois River Waterway Fish Assemblages. Thesis. University of Illinois at UrbanaChampaign, Natural Resources and Environmental Sciences.

Peck, J. H., and M. M. Smart. 1986. "An Assessment of the Aquatic and Wetland Vegetation of the Upper Mississippi River.” Hydrobiologia 136(1): 57-75.

Pegg, M. A., and M. A. McClelland. 2004. "Spatial and Temporal Patterns in Fish Communities along the Illinois River." Ecology of Freshwater Fish 13(2): 125135 .

Putman, J. H., C. L. Pierce, and D. M. Day. 1995. "Relationships between Environmental Variables and Size-Specific Growth Rates of Illinois Stream Fishes.” Transactions of the American Fisheries Society 124(2): 252-261.

Randall, R. G., C. K. Minns, and J. R. M. Kelso. 1995. "Fish Production in Freshwaters: Are Rivers More Productive than Lakes?” Canadian Journal of Fisheries and Aquatic Sciences 52(3): 631-643.

Sampson, S. J., J. H. Chick, and M. A. Pegg. 2009. "Diet Overlap among Two Asian Carp and Three Native Fishes in Backwater Lakes on the Illinois and Mississippi Rivers." Biological Invasions 11(3): 483-496.

Smith, D. L., S. P. Miner, C. H. Theiling, R. Behm, and J. M. Nestler. 2017. Setback Levees: An Innovative, Cost-Effective, and Sustainable Solution for Improved Flood Risk Management. ERDC/EL SR-17-3. Vicksburg, MS: US Army Engineer Research and Development Center. 
Theiling, C. H., 1995. "Habitat Rehabilitation on the Upper Mississippi River." River Research and Applications 11(2): 227-238.

Theiling, C. H., T. A. Kirkeeng, C. P. Haring, and T. A. Dahl. 2018. Levee Setback Utility for Sustainable Mission Integration in the Sangamon River Floodplain. ERDC TR-18-12. Vicksburg, MS: US Army Engineer Research and Development Center.

VonBank, J. A. 2015. An Assessment of Aquatic Invasive Plants in the Illinois River: Water Hyacinth Surveillance, Mapping, Persistence, and Potential Seed Dispersal. INHS Technical Report. Western Illinois University.

Wehrle, B. W., R. M. Kaminski, B. D. Leopold, and W. P. Smith. 1995. "Aquatic Invertebrate Resources in Mississippi Forested Wetlands during Winter." Wildlife Society Bulletin 23(4): 774-783.

Williamson, C. J., and J. E. Garvey. 2005. "Growth, Fecundity, and Diets of Newly Established Silver Carp in the Middle Mississippi River." Transactions of the American Fisheries Society 134(6): 1423-1430.

Yin, Y., J. C. Nelson, and K. S. Lubinski. 1977. "Bottomland Hardwood Forests along the Upper Mississippi River.” Natural Areas Journal 17: 164-173. 


\section{Unit Conversion Factors}

\begin{tabular}{|c|c|c|}
\hline Multiply & By & To Obtain \\
\hline acres & $4,046.873$ & square meters \\
\hline cubic feet & 0.02831685 & cubic meters \\
\hline degrees Fahrenheit & $(F-32) / 1.8$ & degrees Celsius \\
\hline feet & 0.3048 & meters \\
\hline miles (US statute) & $1,609.347$ & meters \\
\hline ounces (mass) & 0.02834952 & kilograms \\
\hline pints (US liquid) & 4.73176 E-04 & cubic meters \\
\hline pints (US liquid) & 0.473176 & liters \\
\hline pounds (mass) & 0.45359237 & kilograms \\
\hline quarts (US liquid) & 9.463529 E-04 & cubic meters \\
\hline square miles & $2.589998 \mathrm{E}+06$ & square meters \\
\hline square yards & 0.8361274 & square meters \\
\hline yards & 0.9144 & meters \\
\hline
\end{tabular}




\section{Acronyms and Abbeviations}

1D one-dimensional

$\mathrm{C}$ carbon

CASM Comprehensive Aquatic System Model

CASM-SL Comprehensive Aquatic System Model-Sangamon levee districts

DIN dissolved inorganic nitrogen

DIP dissolved inorganic phosphorous

DOC dissolved organic carbon

EAV emergent aquatic vegetation

HEC-RAS Hydrologic Engineering Center-River Analysis System

L\&DD levee and drainage district

$\mathrm{N} \quad$ nitrogen

P phosphorus

PAR photosynthetically active radiation

POC particulate organic carbon

SAV submerged aquatic vegetation

TSS total suspended solid

UMR Upper Mississippi River 


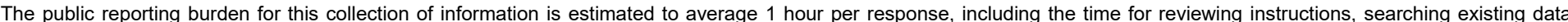

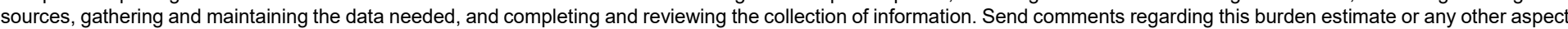

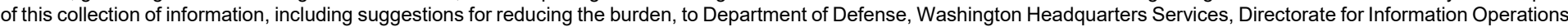

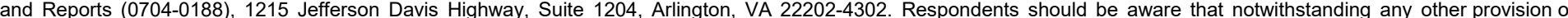
law, no person shall be subject to any penalty for failing to comply with a collection of information if it does not display a currently valid OMB control number. PLEASE DO NOT RETURN YOUR FORM TO THE ABOVE ADDRESS.

\begin{tabular}{l|l|l}
$\begin{array}{l}\text { 1. REPORT DATE } \\
\text { May } 2020\end{array}$ & $\begin{array}{l}\text { 2. REPORT TYPE } \\
\text { Final Report }\end{array}$ & 3. DATES COVERED (FrOm - To)
\end{tabular}

\section{TITLE AND SUBTITLE}

Development and Application of the CASM-SL to Support Nutrient Management in Potential Sangamon River Levee Setbacks

5a. CONTRACT NUMBER

5b. GRANT NUMBER

5c. PROGRAM ELEMENT NUMBER

\section{6. $\operatorname{AUTHOR}(\mathrm{S})$}

Steven M. Bartell, Cindy T. Woodard, Charles H. Theiling, and Travis A. Dahl

5d. PROJECT NUMBER

454633

5e. TASK NUMBER

5f. WORK UNIT NUMBER

\section{PERFORMING ORGANIZATION NAME(S) AND ADDRESS(ES) (see reverse)}

\section{PERFORMING ORGANIZATION REPORT NUMBER}

ERDC/TR-20-9

\section{SPONSORING/MONITORING AGENCY NAME(S) AND ADDRESS(ES)}

US Army Corps of Engineers

Washington, DC 20314-1000

\section{DISTRIBUTION/AVAILABILITY STATEMENT}

Approved for public release; distribution is unlimited.

\section{SUPPLEMENTARY NOTES}

\section{ABSTRACT}

Levee setbacks are defined by the intentional relocation of levees away from the river bank. This placement is often done to reduce flood risk, but it can also have environmental benefits. The Comprehensive Aquatic System Model (CASM) was used to look at the potential fate of nutrients and several environmental benefits for five potential management scenarios along the lower Sangamon River in Illinois. The model results showed that two scenarios were much more environmentally favorable relative to the outcomes considered here. One of the scenarios, where the existing gates were operated to allow the river access to the area behind the levee during extreme floods, was better at nitrogen and phosphorous accumulation. Removing the gates and creating a levee setback at this same site produced more aquatic plants, invertebrates, and fish but was not as effective at nutrient accumulation. This application of CASM demonstrates the potential of the model to provide objective rankings for the environmental benefits of levee setbacks.

\section{SUBJECT TERMS}

Ecosystem services, Environmental management, Flood control, Floodplain management, Levees, Sangamon River (Ill.), Stream restoration

\section{SECURITY CLASSIFICATION OF:}

a. REPORT

\begin{tabular}{|l|l|} 
b. ABSTRACT & c. THIS PAGE \\
Unclassified & Unclassified
\end{tabular}

17. LIMITATION OF ABSTRACT

SAR
18. NUMBER 19a. NAME OF RESPONSIBLE PERSON

OF PAGES

51 Travis A. Dahl $601-634-2371$ 19b. TELEPHONE NUMBER (Include area code) 


\section{PERFORMING ORGANIZATION NAME(S) AND ADDRESS(ES) (continued)}

Coastal and Hydraulics Laboratory

US Army Engineer Research and Development Center 3909 Halls Ferry Rd

Vicksburg, MS 39180-6199

Environmental Laboratory

US Army Engineer Research and Development Center 3909 Halls Ferry Rd

Vicksburg, MS 39180-6199

Cardno, Inc.

7610 Morganton Road

Greenback, TN 37742 